\title{
Endocrine Disrupting Pesticides
}

\author{
Svetlana Hrouzková and Eva Matisová
}

Additional information is available at the end of the chapter

http://dx.doi.org/10.5772/46226

\section{Introduction}

Food and environmental samples represent nowadays an enormous challenge to analytical chemists in their efforts to determine residues of pesticides at trace levels, as pesticides can represent a risk for consumer and also safeguard the biodiversity in the environment. The concern has increased as certain pesticides and other synthetic chemicals may act as pseudo hormones which disrupt the normal function of the endocrine system in humans and wildlife (Colborn et al., 1993; Lintelmann et al., 2003). This specific category of pollutants comprises the compounds that may affect the normal hormonal function or possess endocrine-related functions, known as endocrine disrupting chemicals (EDCs) or endocrine disrupters. During the last decades the interest and concern related to endocrine disrupters among scientists, regulators and public has increased. In the last years a great deal of concern has been expressed worldwide over the increasing levels of EDCs found in the environment. This anxiety is caused by the adverse effects of these pollutants on the hormone systems of humans and wildlife even when present at levels under ppb (Jobling, 2004).

Known and potential EDCs in food and the environment originate from many different sources. Endocrine disrupting pesticides (EDPs) are the largest group of EDCs in numbers compared to other chemical groups. They are active at low concentrations in food daily consuming by adult population and in agricultural commodities consumed in large quantities especially by infants and children. Organisms under development are very sensitive to negative effects of EDPs. Understanding in which and how much biologically active compounds are in the environmental samples or products of human consumption is important not just to scientists and environmentalists, but also to governments, pediatricians, genetics, and the general public (LaFleur \& Schug, 2011).

This contribution is devoted to pesticides that exhibit or are supposed to exhibit endocrine disrupting properties. First, the terms, definition and current state of EDCs list creation are discussed. Then the selected EDPs and their categories are presented. Next the common 
analytical methods including sample preparation for the identification and quantification of EDPs by chromatographic analytical methods at ultratrace concentration level are briefly covered. The combinations of fast and effective sample preparation methods with conventional and fast capillary gas chromatography (GC) are presented. Selective mass spectrometric (MS) detection with negative chemical ionization (NCI) is discussed and compared to electron ionization (EI). The results leading to selectivity enhancement and decrease of the limits of quantification of selected EDPs using mass spectrometer operated in NCI mode are shown. Real-life analysis demonstrates the potential of studied sample preparation followed by fast gas chromatography.

\section{Terms, definitions and background}

The endocrine system is a complex integrative network of glands, hormones and receptors. It provides the key communication and control link between the nervous system and bodily functions such as reproduction, immunity, metabolism and behaviour. The endocrine system uses hormones to act as messengers that regulate reproduction, metabolism, growth, development, natural defences to stress, as well as water, electrolyte, and nutritional balance of the blood. Homeostasis is the balance of functions or levels in the body, returning biological variables to their biochemical baseline when perturbed and keeping them there. Maintaining homeostasis is one of the most important functions of the endocrine system. Therefore, the endocrine system includes number of central nervous system-pituitary-target organ feedback mechanisms that enable the body to react very flexibly on internal or external changes of hormone status (Lintelmann et al., 2003). This complex system is very sensitive toward disturbing influences that can severely impair the whole development of the organisms. A number of naturally occurring and synthetic chemicals have been shown to exert these adverse effects upon the endocrine system across animal classes including mammals. Concern for these chemicals initially focused on chemicals with estrogenic activity, and thus they were commonly referred to as environmental estrogens, or xenoestrogens (Rhomberg \& Seeley, 2005). The initial focus has expanded to include compounds with androgenic activity, as well as thyroid-active chemicals (Rhomberg \& Seeley, 2005). Consequently, also different variable terms appeared, e. g. endocrine disrupter (mainly used in Europe)/endocrine disruptor (in America), hormone mimics, hormone inhibitors, hormonally active chemicals, endocrine modulators (Jobling, 1998). Today, these compounds are commonly referred to as endocrine disrupting chemicals.

By definition adopted by European Commission (EC), "an endocrine disrupter is an exogenous substance or mixture that alters function(s) of the endocrine system and consequently causes adverse health effects in an intact organism, or its progeny, or (sub) populations" (European Commission [EC], Endocrine disrupters website, 2011). EDCs were defined by Unites States Environmental Protection Agency (US EPA) as "an exogenous agent that interferes with synthesis, secretion, transport, metabolism, binding action, or elimination of natural blood-borne hormones that are present in the body and are responsible for homeostasis, reproduction, and developmental process". According to Diamanti-Kandarakis et al., 2009, it is necessary to broaden the term - the EDCs is a 
compound, which through environmental or inappropriate developmental exposures, alters the hormonal and homeostatic systems that enable the organism to communicate and respond to environment.

Exposure to EDCs may cause disorder of endocrine system in a number of ways (Mendes, 2002). Many disrupters interact directly with hormone receptors, whereas some cause indirect activation of hormone receptors. They interfere by mimicking the action of a naturally-produced hormone, such as estrogen or testosterone, and thereby setting off similar chemical reactions in the body. EDCs can interfere by blocking the receptors in cells receiving the hormones (hormone receptors), thereby preventing the action of normal hormones. Some receptors interact with each other, such as through "cross-talk" between the estrogen and the growth factor receptors (Dybing, 2006). In other situations, EDCs may interact with multiple receptors. It is well-known, that inhibition of hormone synthesis and hormone transport, as well as alteration in hormone metabolism can affect endocrine system as the concentration of natural hormones alters. An example of how EDCs can interfere with receptor sites is shown in Fig. 1. The important role of well-working endocrine system functioning is the proper hormone-receptor binding at the appropriate level and time (Fig. 1. A). EDCs can give a weaker or stronger than normal response (Fig. 1. B) at inappropriate times compared to natural body's hormones (LaFleur \& Schug, 2011). At the environmental level, wildlife is particularly vulnerable to the endocrine disrupting effects of pesticides, effects noted in invertebrates, reptiles, fish, birds and mammals were reviewed by Mnif et al., 2007. Many pesticides and industrial chemicals are capable of interfering with the proper function of estrogen, androgen and thyroid hormones at the human level. For example, during pregnancy, lipophilic xenobiotics stored in maternal adipose tissue can be mobilized and enter the blood circulation and reach the placenta. As it was searched by LopezEspinosa et al., 2007, the presence of more pesticides in placenta was significantly associated with lower birth weight.

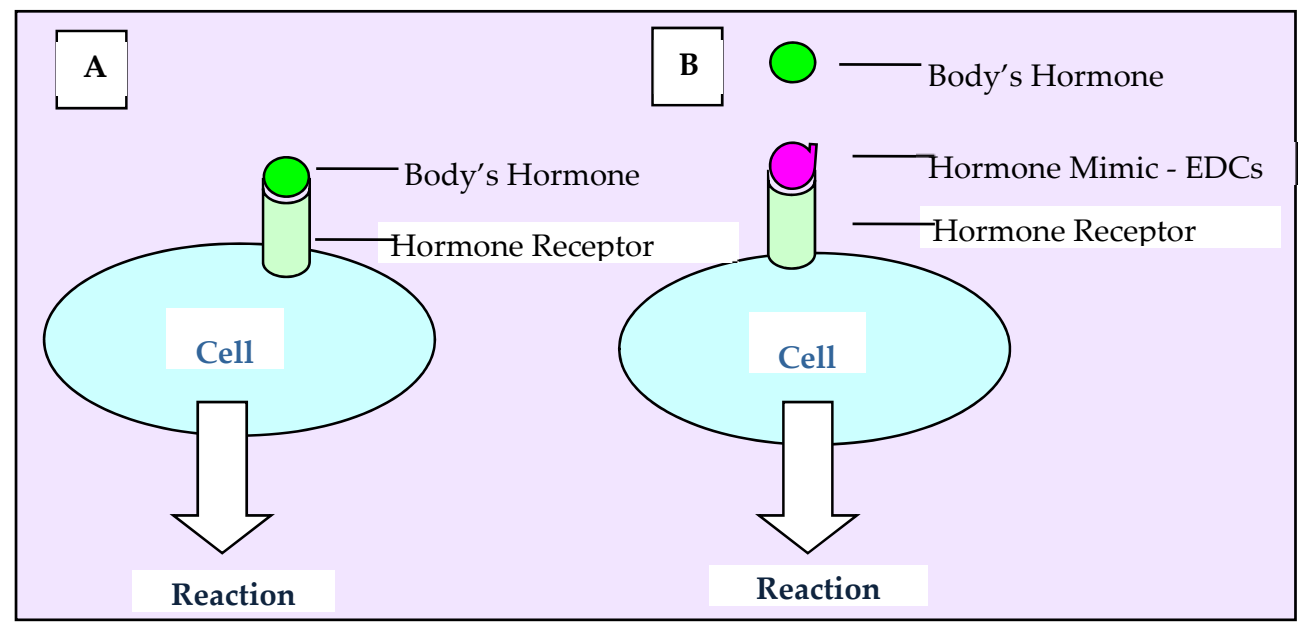

Figure 1. Outline of normal hormonal response (A) and EDCs interference with hormone receptors (B). 
Changes in hormone levels affect developing organisms more than adults and can result in abnormalities in reproduction, growth, development and can disorder the immune system, as it was discussed by Mnif et al., 2011. A central feature of endocrine disruption is that may cause detrimental effects on organisms at very low chemical concentrations (Fang et al., 2001). Effects of EDCs at very low concentrations can be different from effects of the same chemical at higher concentrations (Colborn, 2012). Traditional approaches to determining safe exposure levels (for example, chemical risk assessments) do not work with EDCs.

\section{Compounds of interest}

The groups of molecules identified as EDCs are highly heterogeneous and include natural chemicals found in human and animal food (phytoestrogenes), synthetic chemicals used as industrial solvents/lubricants and their by-products, plastics, plasticizers, pesticides, pharmaceuticals, etc. The scope of EDCs here has been narrowed specifically to known and potential endocrine disrupting pesticides.

The first list of suspected EDCs was published in scientific literature in 1993 by Theo Colborn (Colborn et al., 1993), followed by popular book for the layperson "Our stolen future" (Colborn et al., 1996). This book was instrumental in public awareness of the need to find out more.

In United States, the US EPA has been authorized to screen all manufacturing or processing chemicals and formulations for potential endocrine activity. The Endocrine Disruption Screening Program (EDSP) of EPA is mandated to use validated methods for screening and testing chemicals to identify potential endocrine disruptors, determine adverse effects, doseresponse, assess risk and ultimately manage risk under laws. It is realized in two-tiered screening and testing process. In Tier 1, EPA hopes to identify chemicals that have potential to interact with the endocrine system. In Tier 2, EPA determines the specific effect caused by each disruptor and establishes the dose at which the effect occurs. In 2009, EPA released the Final list of Chemicals for Tier 1 Screening in the EDSP (United States Environmental Protection Agency [US EPA] Document, 2009), which is an update of Initial list from 2007 (some chemicals were removed). On November 2010 the US EPA published the second list of chemicals for further testing. This list of 134 chemicals includes a large number of pesticides (US EPA Document, 2010). The selection showing pesticides for EDSP screening is summarized in Table 1.

The European Union (EU) has done extensive work towards official designation of endocrine disrupting substances, collecting literature studies on many chemicals. In December 1999, the European Commission adopted a document entitled "Community Strategy for Endocrine Disrupters" to address the problem of EDCs. A part of this strategy was to establish a priority list that are presumably responsible for damaging human health by interference with hormones and to require the further evaluation of their role in endocrine disruption (EC document, 1999). The creation of the list was based on the published studies of these chemicals and was divided into categories according to 


\begin{tabular}{|c|c|}
\hline 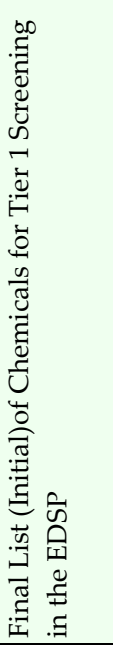 & $\begin{array}{l}\text { Abamectin / 71751412; Acephate / 30560191; Atrazine / 1912249; Benfluralin / 1861401; } \\
\text { Bifenthrin / 82657043; Captan / 133062; Carbamothioic acid, dipropyl-, s-ethyl ester / 759944; } \\
\text { Carbaryl / 63252; Carbofuran / 1563662; Chlorothalonil / 1897456; Chlorpyrifos / 2921882; } \\
\text { Cyfluthrin / 68359375; Cypermethrin / 52315078; 2,4-D (2,4-dichlorophenoxy acetic acid) / } \\
\text { 94757; DCPA (chlorthal-dimethyl) / 1861321; Diazinon / 333415; Dichlobenil / 1194656; } \\
\text { Dicofol / 115322; Dimethoate / 60515; Disulfoton / 298044; Endosulfan / 115297; Esfenvalerate } \\
\text { / 66230044; Ethoprop / 13194484; Fenbutatin oxide / 13356086; Flutolanil / 66332965; Folpet / } \\
\text { 133073; Gardona (cis-isomer) / 22248799; Glyphosate / 1071836; Imidacloprid / 138261413; } \\
\text { Iprodione / 36734197; Linuron / 330552; Malathion / 121755; Metalaxyl / 57837191; } \\
\text { Methamidophos / 10265926; 4,7-Methano-1H-isoindole-1,3(2H)-dione,2-(2-ethylhexyl)- } \\
\text { 3a,4,7,7a-tetrahydro- / 113484; Methidathion / 950378; Methomyl / 16752775; Methyl } \\
\text { parathion / 298000; Metolachlor / 51218452; Metribuzin / 21087649; Myclobutanil / 88671890; } \\
\text { Norflurazon / 27314132; o-Phenylphenol / 90437; Oxamyl / 23135220; Permethrin / 52645531; } \\
\text { Phosmet / 732116; Piperonyl butoxide / 51036; Propachlor / 1918167; Propargite / 2312358; } \\
\text { Propiconazole / 60207901; Propyzamide / 23950585; Pyridine, 2-(1-methyl-2-(4- } \\
\text { phenoxyphenoxy) ethoxy)- / 95737681 ; Quintozene / 82688; Resmethrin / 10453868; Simazine } \\
\text { / 122349; Tebuconazole / 107534963; Triadimefon / 43121433; Trifluralin / 1582098; }\end{array}$ \\
\hline 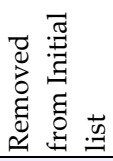 & $\begin{array}{l}\text { Aldicarb / 116063; ; Allethrin / 584792; Azinphos-Methyl / 86500; Dichlorvos / 62737; } \\
\text { Fenvalerate / 51630581; Methiocarb / 2032657; }\end{array}$ \\
\hline 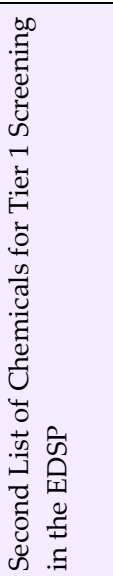 & $\begin{array}{l}\text { Acetochlor / 34256-82-1; Acrolein / 107-02-8; Alachlor / 15972-60-8; Bensulide / 741-58-2; } \\
\text { Clethodim / 99129-21-2; Clofentezine / 74115-24-5; Clomazone / 81777-89-1; Coumaphos / 56- } \\
\text { 72-4; Cyanamide / 420-04-2; Cyromazine / 66215-27-8; Denatonium saccharide / 90823-38-4; } \\
\text { Dicrotophos / 141-66-2; Dimethipin / 55290-64-7; Diuron / 330-54-1; Endothall / 145-73-3; } \\
\text { Etofenprox / 80844-07-1; Fenarimol / 60168-88-9; Fenoxaprop-p-ethyl / 71283-80-2; } \\
\text { Fenoxycarb / 72490-01-8; Flumetsulam / 98967-40-9; Fomesafen sodium / 108731-70-0; } \\
\text { Fosetyl-Al (Aliette) / 39148-24-8; Glufosinate ammonium / 77182-82-2; Hexythiazox / 78587- } \\
\text { 05-0; Isoxaben / 82558-50-7; Lactofen / 77501-63-4; Molinate / 2212-67-1; Oxydemeton-methyl } \\
\text { / 301-12-2; Oxyfluorfen / 42874-03-3; Paclobutrazol / 76738-62-0; p-Dichlorobenzene / 106-46- } \\
\text { 7; Pentachlorophenol / 87-86-5; Picloram / 1918-02-1; Profenofos / 41198-08-7; Propetamphos / } \\
\text { 31218-83-4; Propionic acid / 79-09-4; Pyridate / 55512-33-9; Quinclorac / 84087-01-4; } \\
\text { Quizalofop-p-ethyl / 100646-51-3; Sodium tetrathiocarbonate / 7345-69-9; Sulfosate / 81591- } \\
\text { 81-3; Temephos / 3383-96-8; Terbufos / 13071-79-9; Thiophanate-methyl / 23564-05-8; } \\
\text { Triflumizole / 68694-11-1; Trinexapac-ethyl / 95266-40-3; Triphenyltin hydroxide (TPTH) / 76- } \\
\text { 87-9; Vinclozolin / 50471-44-8; Xylenes / 1330-20-7; Ziram / 137-30-4; }\end{array}$ \\
\hline
\end{tabular}

Table 1. The selection of pesticide active ingredients (compound name/ chemical abstract number CAS) from Initial and Second List of Chemicals according to US EPA studied in Tier 1 in the frame of US EDSP.

documented/potential endocrinal effect. This list of chemicals divides compounds into the following categories according to their impact on endocrine system:

- Category 1 - endocrinal effect recorded at least on one type of animal;

- Category 2 - a record of biological activity in vitro leading to disruption;

- Category 3 - not enough evidence or no evidence data to confirm/ disconfirm endocrinal effect of tested chemicals. 
Acetochlor / 34256-82-1; Alachlor / 15972-60-8; Amitrol = Aminotriazol / 61-82-5; Atrazine / 1912-24-9; Beta-HCH / 319-85-7; Bifenthrin / 82657-04-3; Bis-OH-Methoxychlor = 1,1,1-Trichloro-2,2-bis(4-hydroxyphenyl)ethane (HTPE) / 63-25-2; Carbaryl / 63-25-2; Cis-Nonachlor / 5103-73-1; Cyhalothrin / 91465-08-6; DDT (technical) = clofenotane / 50-29-3; Deltamethrin / 52918-63-5; Dibromoethane (EDB) / 106-93-4; Dibromochloropropane (DBCP) / 96-12-8; 1,3-Dichloro-2,2-bis(4-methoxy-3-methylphenyl)propane/ 30668-06-5; 2,4-

Dichlorophenoxybutyric acid = 2,4-DB / 326354-18-7; Ethyl-4-hydroxybenzoate / 120-47-8; Ethylene thiourea (ETU) / 96-45-7; Fenarimol / 60168-88-9; Fenitrothion / 122-14-5; Fentin acetate $=$ triphenyltin acetate / 900-95-8; Gamma-HCH (Lindane) / 58-89-9; Hexachlorobenzene (HCB) / 118-74-1; Hexachlorocyclohexane / 608-73-1; Chlordane (technical)/ 12789-03-6; Chlordane (cis- and trans-) / 57-74-9; Chlordimeform / 6164-98-3; Ioxynil / 1689-83-4; Kepone (Chlordecone) / 143-50-0; Ketoconazol / 65277-42-1; Linuron (Lorox) / 330-55-2; 4-MeO-o,p'DDE / 65148-81-4; 4-MeO-o,p'-DDT / 65148-72-3; 5-MeO-o,p'-DDD / 65148-75-6; 5-MeO-o,p'-DDE / 65148-82-5; 5MeO-o,p'-DDT / 65148-74-5; m,p'-DDD / 4329-12-8; Mancozeb / 8018-01-7; Maneb / 12427-38-2; 3-MeO-o,p'-DDE / 65148-80-3; Metam Natrium / 137-42-8; Methoxychlor / 72-43-5; Methyl p-Hydroxybenzoate / 99-76-3; Metiram (Metiram-complex) / 9006-42-2; Metribuzin / 21087-64-9; Mirex / 2385-85-5; Nitrofen / 1836-75-5; Propylparaben (n-propyl p-hydroxybenzoate) / 94-13-3; 3-OH-o,p'-DDT / 43216-70-2; 5-OH-o,p'-DDT / 65148-73-4; o,p'-DDAglycinat = N-[(2-chlorophenyl)(4-chlorophenyl) acettyl]glycin / 65148-83-6; o,p'-DDD / 53-19-0; o,p'-DDE / 342482-6; o,p'-DDMU / 14835-94-0; o,p'-DDT / 789-02-6; Omethoate / 1113-02-6; p,p'-DDD / 72-54-8; p, p'-DDE / 72-559; p,p'-DDT = clofenotane / 50-29-3; p,p'-Methoxychlor / 72-43-5; Pentachlorophenol (PCP) / 87-86-5; Phenol, 2[[(tributylstannyl)oxy]carbonyl]- / 4342-30-7; Picloram / 1918-02-1; Procymidon / 32809-16-8; 2-Propenoic acid, 2methyl-, methyl ester = Stannane, tributylmeacrylate / 326354-18-7; Quinalphos = Chinalphos / 13593-03-8; Resmethrin / 10453-86-8; Stannane, (benzoyloxy)tributyl- / 4342-36-3; Stannane, tributyl[(1-oxo-9,12octadecadienyl)oxy]-, (Z,Z)- / 24124-25-2; Stannane, tributyl[[[1,2,3,4,4a,4b,5,6,10,10a-decahydro-1,4a-dimethyl7-(1-methylethyl)-1-phenanthrenyl]carbonyl]oxy]-,[1R-(1a,4ab,4ba,10aa)]- / 26239-64-5; Stannane, tributylfluoro/ 1983-10-4; Terbutryn / 886-50-0; Thiram / 137-26-8; 1,1,1,2-Tetrachloro-2,2-bis(4-chlorophenyl) ethane (tetrachloro DDT) / 3563-45-9; Toxaphene = Camphechlor / 8001-35-2; Trans-Nonachlor / 39765-80-5; Tributyl[(2methyl-1-oxo-2-propenyl)oxy]stannane / 2155-70-6; 1,1,1-Trichloro-2,2-bis(4-chlorophenyl) ethane / 2971-22-4; Trifluralin / 1582-09-8; Vinclozolin / 50471-44-8; Zineb / 12122-67-7;

Acephate / 30560-19-1; Aldicarb / 116-06-3; Aldrin / 309-00-2; Allethrin (d- trans allethrin) / 584-79-2; Bromoxynil / 1689-84-5; Carbendazim / 10605-21-7; Carbofuran / 1563-66-2; 4-Chloro-2-methylphenol / 1570-64-5; 4-Chloro3-methylphenol / 59-50-7; p-Cresol /106-44-5; Cyanazine / 21725-46-2; Cypermethrin / 52315-07-8; Delta-HCH / 319-86-8; p,p'-DDA / 83-05-6; Diazinon / 333-41-5; 2,4-Dichlorophenoxy acetic acid (2,4-D) / 94-75-7; Dicofol = Kelthane / 115-32-2; Dieldrin / 60-57-1; Diisobutylphthalate / 84-69-5; Dimethoate / 60-51-5; Diuron / 330-54-1; Elsan = Dimephenthoate / 2597-03-7; Endosulfan / 115-29-7; Endosulfan (alpha) / 959-98-8; Endosulfan (beta) / 33213-65-9; Endrin / 72-20-8; Etridiazole / 2593-15-9; Fenothrin = sumithrin / 26002-80-2; Fenoxycarb / 72490-01-8; Fenvalerate / 51630-58-1; Fluvalinate / 69409-94-5; Heptachlor / 76-44-8; Chlorfenvinphos / 470-90-6; Iprodione / 36734-19-7; Malathion / 121-75-5; Methomyl /16752-77-5; Methylbromide (bromomethane) / 74-83-9; Methylparathion /298-00-0; Mevinphos = Phosdrin /7786-34-7; 4-Nitrophenol / 100-02-7; Oxychlordane /2730413-8; Parathion = Parathion(-ethyl) / 56-38-2; Permethrin / 52645-53-1; o-Phenylphenol / 90-43-7; Phosophamidon / 13171-21-6; Photomirex / 39801-14-4; Piperonyl butoxide / 51-03-6; Prochloraz / 67747-09-5; Prometryn /728719-6; Propanil / 709-98-8; Pyrethrin / 121-29-9; Simazine / 122-34-9; Triadimefon / 43121-43-3; Triadimenol / $123-$ 88-6; Trichlorfon = Dipterex / 52-68-6; 2,4,5-Trichlorophenoxy acetic acid (2,4,5-T) / 93-76-5; Ziram / 137-30-4;

Abamectin / 71751-41-2; Amitraz / 33089-61-1; Azadirachtin / 11141-17-6; Benomyl / 17804-35-2; Bitertanol / 55179-31-2; Bromacil / 314-40-9; Clofentezine = chlorfentezine / 74115-24-5; Cyproconazole / 94361-07-6; Demefion / 682-80-4; Demeton-s-methyl / 919-86-8; Difenoconazole / 119446-68-3; Dichlorvos /62-73-7; Dimethylformamide (DMFA) / 68-12-2; Dinitrophenol / 25550-58-7; Dinoseb / 88-85-7; Diphenyl / 92-52-4; Epiconazole / 133855-98-8; Epoxiconazole / 135319-73-2; Esfenvalerate / 66230-04-4; Ethofenprox / 80844-07-1; Fenbuconazole / 114369-43-6; Fipronil / 120068-37-3; Fluazifop-butyl / 69806-50-4; Flutriafol / 76674-21-0; Formothion / 682-80-4; Glufosinate / 51276-47-2; Glufosinate-ammonium / 70393-85-0; Glyphosate / 1071-83-6; Heptachlor-epoxide / 1024-57-3; Chlordene / 3734-48-3; Chlorpyrifos / 2921-88-2; Imazalil / 3554-44-0; Molinate / 2212-67-1; Myclobutanil / 88671-89-0; Nabam / 142-59-6; Octachlorostyrene / 29082-74-4; Oryzalin / 19044-88-3; Oxydemeton-methyl / 301-12-2; Paraquat / 4685-14-7; Penconazole / 66246-88-6; Pendimethalin / 40487-42-1; Pentachloronitrobenzene (Quintozene) / 82-68-8; Prodiamine / 29091-21-2; Pronamide / 23950-58-5; Propiconazole / 60207-90-1; Ronnel = Fenchlorfos / 299-84-3; Tebuconazole / 107534-96-3; Tetrachlorvinphos = Gardona / 22248-79-9; Thiazopyr / 117718-60-2;

Table 2. The selection of endocrine disrupting pesticides (compound name/ chemical abstract number CAS) according to EU prioritization of EDCs into 3 categories. 
For some chemicals the production and usage was already forbidden and others are still under testing. Majority of substances registered in this list of chemicals are pesticides (EC document, 2007). The selection of pesticides is summarized in Table. 2 according to their Category. From a total of 564 chemicals that had been suggested by various organizations or in published papers or reports as being suspected EDCs, 147 were considered likely to be either persistent in the environment or produced at high volumes. Of these, however, in a first assessment clear evidence of endocrine disrupting activity was noted for only 66 (assigned Category 1 using the criteria adopted in the study). A further 52 chemicals showed some evidence suggesting potential activity (Category 2). In total 118 substances were categorized in the first exercise of priority setting. Of the 66 chemicals in Category 1 , humans were considered likely to be exposed to 60 .

Selected substances have been included as persistent organic pollutants in the Stockholm Convention, which is a global treaty to protect human health and the environment from these compounds (EC document, 2006).

In June 2007, the new EU policy on chemicals, REACH - Registration, Evaluation, Authorization and Restriction of Chemicals, entered into force. The goal of REACH is a prompt, effective process for identifying the most hazardous chemicals on the European market and replacing them with safer alternatives. At the heart of the Authorization process is a "candidate list" of chemicals that meet the criteria of "Substances of Very High Concern" (SVHC) defined in the legislation, such as those that may cause cancer or persist in our bodies and the environment for long periods of time. Under REACH, SVHC are subject to the greatest scrutiny. The EU creates a specific list of these undesirable substances which will oblige importers, producers and downstream users to seek special authorization for continued use. Authorization may be denied, because REACH contains a provision that could replace some of these dangerous substances with safer alternatives. Under this activity, the International Chemical Secretariat (ChemSec) is a non-profit organization working for a toxic free world and publishing the SIN List (Substitute It Now). The SIN List applies REACH's own criteria to identify SVHC, and with the SIN 2.0 List update encompasses 378 chemicals. It contains 22 substances identified solely due to their endocrine disrupting properties. The following pesticides are included: Thiram (CAS 137-26-8), Zineb (CA S 12122-67-7).

\section{EDPs analysis}

Detection of EDPs and subsequent screening require sensitive and selective instrumental analytical techniques with sufficiently low limits of detection and quantification. Analyzing the EDPs at low concentration levels requires multistep sample preparation including cleaning and preconcentration of the resulting extract. As EDPs represent structurally diverse classes of substances, plentiful analytical methods could be applied for the identification and quantification of these compounds (Lagana et al., 2004; Petrovič et al., 2002). The most efficient approach to EDPs residues analysis involves the use of chromatographic methods (Comerton et al., 2009). Recently, methods based on biosensors have also been used (Bezbaruah \& Kalita, 2010; Dostálek et al., 2007). Analytical techniques 
as GC and liquid chromatography (LC) combined with MS or tandem MS are the techniques most frequently used and can reach satisfactory selectivity and sensitivity analyzing EDPs in complex food matrices mainly of food and environmental origin (Alder et al., 2006). Comparing mass-based methods with other analytical methods, such as Estrogen responsive chemically activated luciferase expression, Yeast estrogen screen, Enzyme-linked immunosorbent assay, it was shown that methods with MS detection (GC-MS, LC-MS, GCMS/MS , LC-MS/MS) show lower detection limits (Chang et al., 2009). Comparing detection limits of enzymatic methods for the detection of organochlorine, organophosphate and carbamate pesticides with chromatographic methods it was concluded, that enzymatic methods achieve limits of detection in $\mu \mathrm{g} / \mathrm{l}$, whereas traditional chromatographic methods are often able to detect pesticides in ng/l (Van Dyk \& Pletschke, 2011).

In the next part we will focus on analytical methods with limit of detection/quantification in the trace concentration level or ultratrace region and we will cite methods well-suited for analytical tests of low-level EDPs in food, environmental and biological samples.

Capillary gas chromatography coupled to MS detection has developed into a primary technique for identification and quantification of many EDCs using small bench-top instruments with sophisticated data systems (Holland, 2003). Electron ionization is the ionization technique of the first choice. In cases requiring enhanced sensitivity and selectivity the negative/positive chemical ionization is employed (Húšková et al., 2009a, 2009b, 2010a).

Within gas chromatographic techniques, fast GC technique satisfies the present day demands on faster and cost-effective analysis. Nowadays, fast GC can be performed on commercial gas chromatographs, which are standardly equipped with high-speed injection systems, electronic gas pressure control, rapid oven heating/cooling and fast detection (Dömötörová \& Matisová, 2008). Advances in LC-MS interfacing, namely introduction of electrospray (ESI) and atmospheric pressure chemical ionization (APCI) have enabled sensitivity and reliability that are suitable for routine determinations of EDCs, particularly for more polar compounds that would require derivatization for GC-MS. LC-MS can reduce clean-up requirements over HPLC-UV (high performance liquid chromatography with ultraviolet detection), although care must be taken with matrix effects on ESI responses that may affect quantitation (Holland, 2003).

Signal enhancement and suppression due to matrix effects are reduced by the use of isotopelabelled internal standards or by application of matrix-matched standards. Tandem MS available on triple quadrupole, ion trap and hybrid analyzers are valuable for confirmation of identity, reduction of high background signals. They provide low limits of detection without the need for derivatization and sometimes also without the need of complicated sample preparation.

The overview of latest analytical methods combining preconcentration and chromatographic analytical methods for analysis of EDPs in food, environmental, and biological samples are summarized in Table 3. Various groups of EDPs were investigated by GC as carbamates, organochlorines, organophosphorous, organothiophosphates, organotins, triazines and others. Analysed samples varied from indoor air, water, sediments, food, to biological 


\begin{tabular}{|c|c|c|c|c|c|c|}
\hline Analytes & Matrix & $\begin{array}{c}\text { Sample } \\
\text { preparation }\end{array}$ & $\begin{array}{l}\text { Injection } \\
\text { technique }\end{array}$ & LOD & $\begin{array}{c}\text { Separation and } \\
\text { detection } \\
\text { technique }\end{array}$ & References \\
\hline \multicolumn{7}{|c|}{ GC } \\
\hline 23 pesticides & apples & QuEChERS & PTV, SVV & $\begin{array}{l}\text { EI: } 0.09-3.12 \\
\mu \mathrm{g} / \mathrm{kg} \\
\mathrm{NCI}: 1.9-935 \\
\mathrm{ng} / \mathrm{kg}\end{array}$ & $\begin{array}{l}\text { GC-MS (SIM) } \\
\text { quadrup., } \\
\text { NCI, EI }\end{array}$ & $\begin{array}{l}\text { Húšková et } \\
\text { al., 2009a }\end{array}$ \\
\hline 25 pesticides & apples & QuEChERS & PTV, SVV & $\begin{array}{l}\text { EI: } 0.02-6.32 \\
\mu \mathrm{g} / \mathrm{kg} \\
\mathrm{NCI}: 0.15-619.3 \\
\mathrm{ng} / \mathrm{kg}\end{array}$ & $\begin{array}{l}\text { fast GC-MS } \\
\text { (SIM) } \\
\text { quadrup., } \\
\text { NCI, EI }\end{array}$ & $\begin{array}{l}\text { Húšková et } \\
\text { al., 2009b }\end{array}$ \\
\hline 20 OCPs & $\begin{array}{l}9 \text { vegetable } \\
\text { matrices }\end{array}$ & $\begin{array}{l}\text { SBSE (PDMS } 47 \\
\mu \mathrm{l})\end{array}$ & $\begin{array}{l}\text { LVI - PTV, } \\
\text { SVV }\end{array}$ & $<10 \mu \mathrm{g} / \mathrm{kg}$ & $\begin{array}{l}\text { GC-MS (SIM) } \\
\text { quadrup., EI }\end{array}$ & $\begin{array}{l}\text { Barrida- } \\
\text { Pereira et al., } \\
2010\end{array}$ \\
\hline 29 pesticides & $\begin{array}{l}\text { fruit and } \\
\text { vegetables }\end{array}$ & QuEChERS & PTV, SVV & $\leq 5 \mu \mathrm{g} / \mathrm{kg}$ & $\begin{array}{l}\text { fast GC-MS } \\
\text { (SIM) } \\
\text { quadrup., EI }\end{array}$ & $\begin{array}{l}\text { Húšková et } \\
\text { al., 2010b } \\
\text { Hercegová et } \\
\text { al., } 2010\end{array}$ \\
\hline 35 pesticides & $\begin{array}{l}\text { fruit and } \\
\text { vegetables }\end{array}$ & QuEChERS & PTV, SVV & $\begin{array}{l}\mathrm{EI}: \leq 5 \mu \mathrm{g} / \mathrm{kg} \\
\mathrm{NCI}: \leq 1 \mu \mathrm{g} / \mathrm{kg}\end{array}$ & $\begin{array}{l}\text { fast GC-MS } \\
\text { (SIM) } \\
\text { quadrup., EI, } \\
\text { NCI }\end{array}$ & $\begin{array}{l}\text { Hrouzková et } \\
\text { al., } 2011\end{array}$ \\
\hline $\begin{array}{l}9 \text { pesticides, } \\
\text { phtalates, } \\
1 \mathrm{PAH}\end{array}$ & water & on-line SPE & $\begin{array}{l}\text { on-column, } \\
\text { retaining } \\
\text { precolumn, } \\
\text { SVV }\end{array}$ & $0.1-20 \mathrm{ng} / \mathrm{l}$ & $\begin{array}{l}\text { GC-MS (FS) } \\
\text { quadrup., EI }\end{array}$ & $\begin{array}{l}\text { Brossa et al., } \\
2002\end{array}$ \\
\hline $\begin{array}{l}11 \text { pesticides, } \\
\text { phthalates }\end{array}$ & water & on-line SPE & $\begin{array}{l}\text { LVI-PTV, } \\
\text { SVV }\end{array}$ & $1-36 \mathrm{ng} / \mathrm{l}$ & $\begin{array}{l}\text { GC-MS (FS) } \\
\text { quadrup., EI }\end{array}$ & $\begin{array}{l}\text { Brossa et al., } \\
2003\end{array}$ \\
\hline $\begin{array}{l}\text { HCB, atrazine, } \\
\text { lindane, } \\
\text { vinclozolin, } \\
\text { malathion, aldrin, } \\
\alpha \text {-endosulfan, 4,4'- } \\
\text { DDE, dieldrin, } \\
\text { endrin, } 4,4^{\prime} \text {-DDT }\end{array}$ & river water & $\begin{array}{l}\text { SBSE (PDMS } 63 \\
\mu \mathrm{l})\end{array}$ & $\begin{array}{l}\text { split/ } \\
\text { splitless, } \\
\text { LVI - PTV, } \\
\text { SVV }\end{array}$ & $0.01-0.24 \mu \mathrm{g} / 1$ & $\begin{array}{l}\text { GC-MS (FS), } \\
\text { quadrup., EI }\end{array}$ & $\begin{array}{l}\text { Peñalver et } \\
\text { al., } 2003\end{array}$ \\
\hline $\begin{array}{l}15 \text { herbicides, } 7 \\
\text { OPPs, } 17 \text { OCPs }\end{array}$ & water & $\begin{array}{l}\text { SBSE (PDMS } 47 \\
\mu \mathrm{l})\end{array}$ & PTV, SVV & $0.025-0.400 \mu \mathrm{g} / \mathrm{l}$ & $\begin{array}{l}\text { GC-MS (SIM) } \\
\text { quadrup., EI }\end{array}$ & $\begin{array}{l}\text { Serôdio \& } \\
\text { Nogueira, } \\
2004\end{array}$ \\
\hline $\begin{array}{l}32 \text { EDCs and } \\
\text { pesticides }\end{array}$ & water & $\begin{array}{l}\text { SPE (LiChrolut } \\
\text { EN/RP-18, Strata } \\
X)\end{array}$ & splitless & 5.3-95.9 ng/1 & $\begin{array}{l}\text { GC-MS/MS } \\
\text { (MRM), } \\
\text { EI, quad., }\end{array}$ & $\begin{array}{l}\text { Mansilha et } \\
\text { al., } 2010\end{array}$ \\
\hline 15 OCPs & $\begin{array}{l}\text { (i): water } \\
\text { (ii): sediments }\end{array}$ & $\begin{array}{l}\text { (i): LLE } \\
\text { (ii): Soxhlet } \\
\text { extraction, MAE }\end{array}$ & splitless & $\begin{array}{l}\text { (i): } 5.5-20.6 \mathrm{ng} / \mathrm{l} \\
\text { (ii): } 0.6-2.1 \\
\mu \mathrm{g} / \mathrm{kg}\end{array}$ & GC-ECD & $\begin{array}{l}\text { Fatoki \& } \\
\text { Awofolu, } \\
2003\end{array}$ \\
\hline $\begin{array}{l}58 \text { potential EDCs } \\
\text { and PPCPs ( } 18 \\
\text { pesticides) }\end{array}$ & $\begin{array}{l}\text { drinking water, } \\
\text { surface, ground, } \\
\text { waste water } \\
\text { (raw and } \\
\text { treated) }\end{array}$ & SPE (HLB), LLE & splitless & $1-10 \mathrm{ng} / \mathrm{l}$ & $\begin{array}{l}\text { GC-MS/MS, EI, } \\
\text { IT; }\end{array}$ & $\begin{array}{l}\text { Trenholm et } \\
\text { al., } 2006\end{array}$ \\
\hline $\begin{array}{l}6 \text { EDC herbicides } \\
\text { and } 3 \text { degrade. } \\
\text { products }\end{array}$ & $\begin{array}{l}\text { natural surface } \\
\text { water }\end{array}$ & $\begin{array}{l}\text { SPE (Bond Elut- } \\
\text { ENV) }\end{array}$ & splitless & 2.3-115 ng/l & $\begin{array}{l}\text { GC-MS (SIM) } \\
\text { EI, quadrup. }\end{array}$ & $\begin{array}{l}\text { Nevado et al., } \\
2007\end{array}$ \\
\hline
\end{tabular}




\begin{tabular}{|c|c|c|c|c|c|c|}
\hline Analytes & Matrix & $\begin{array}{c}\text { Sample } \\
\text { preparation }\end{array}$ & $\begin{array}{l}\text { Injection } \\
\text { technique }\end{array}$ & LOD & $\begin{array}{c}\text { Separation and } \\
\text { detection } \\
\text { technique }\end{array}$ & References \\
\hline $\begin{array}{l}\text { OPPs, OCPs, } \\
\text { herbicides, PAHs, } \\
\text { PCBs, phenols, } \\
\text { organotins }\end{array}$ & $\begin{array}{l}\text { estuarine and } \\
\text { coastal water, } \\
\text { sediments }\end{array}$ & $\begin{array}{l}\text { SPE (Supelclean } \\
\text { ENVI-18) }\end{array}$ & $\begin{array}{l}\text { LVI-PTV, } \\
\text { SVV }\end{array}$ & $10-250 \mu \mathrm{g} / \mathrm{l}$ & $\begin{array}{l}\text { GC-MS (SIM, } \\
\text { FS) } \\
\text { quadrup., EI }\end{array}$ & $\begin{array}{l}\text { Almeida et } \\
\text { al., } 2007\end{array}$ \\
\hline $\begin{array}{l}33 \text { multi-class } \\
\text { pollutants }\end{array}$ & $\begin{array}{l}\text { wastewaters, } \\
\text { surface and } \\
\text { ground waters }\end{array}$ & SPE & $\begin{array}{l}\text { PTV, SVV; } \\
\text { valve }\end{array}$ & $\begin{array}{l}0.2 \text { and } 88.9 \\
\text { ng/1 }\end{array}$ & $\begin{array}{l}\text { GC-MS } \\
\text { LC-MS/MS }\end{array}$ & $\begin{array}{l}\text { Baugros et } \\
\text { al., } 2008\end{array}$ \\
\hline \begin{tabular}{|l|} 
EDCs (1 pesticide), \\
carbamazepine, \\
pharmaceuticals
\end{tabular} & $\begin{array}{l}\text { wastewater } \\
\text { irrigated soil }\end{array}$ & $\begin{array}{l}\text { ASE, isolation SPE } \\
\text { (Oasis HLB) }\end{array}$ & splitless & $0.25-2.5 \mathrm{ng} / \mathrm{g}$ & $\begin{array}{l}\text { GC-MS (SIM, } \\
\text { FS) } \\
\text { EI, quadrup. }\end{array}$ & $\begin{array}{l}\text { Durán- } \\
\text { Alvarez et al., } \\
2009\end{array}$ \\
\hline $\begin{array}{l}\text { PBDEs, PCBs, } \\
\text { insecticides, } \\
\text { phthalates }\end{array}$ & $\begin{array}{l}\text { indoor dust } \\
\text { from vacuum } \\
\text { cleaner }\end{array}$ & $\begin{array}{l}\text { Soxhlet extraction, } \\
\text { alumina cleaning }\end{array}$ & n. r. & 3-10 ng/g & $\begin{array}{l}\text { GC-MS (SIM) } \\
\text { EI, quadrup. }\end{array}$ & $\begin{array}{l}\text { Hwang et al., } \\
2008\end{array}$ \\
\hline 18 OCPs & $\begin{array}{l}\text { placenta } \\
\text { samples from } \\
\text { woman } \\
\end{array}$ & $\begin{array}{l}\text { SLE (Alumine), } \\
\text { purification - } \\
\text { preparative LC }\end{array}$ & n.r. & n.r. & $\begin{array}{l}\text { GC-ECD } \\
\text { GC-MS }\end{array}$ & $\begin{array}{l}\text { Lopez- } \\
\text { Espinosa et } \\
\text { al., } 2007 \\
\end{array}$ \\
\hline \multicolumn{7}{|c|}{ HPLC } \\
\hline $\begin{array}{l}58 \text { potential EDCs } \\
\text { and PPCPs (18 } \\
\text { pesticides) }\end{array}$ & $\begin{array}{l}\text { drinking, } \\
\text { surface, ground, } \\
\text { waste water }\end{array}$ & SPE (HLB), LLE & valve & $1-10$ ng/l & $\begin{array}{l}\text { LC-MS/MS, } \\
\text { ESI+, ESI-, } \\
\text { APCI, } \\
\text { triplequad. } \\
\text { (MRM) } \\
\end{array}$ & $\begin{array}{l}\text { Trenholm et } \\
\text { al., } 2006\end{array}$ \\
\hline $\begin{array}{l}9 \text { EDCs (3 } \\
\text { herbicides), } 19 \\
\text { PPCPs }\end{array}$ & $\begin{array}{l}\text { water, } \\
\text { wastewater } \\
\text { irrigated soils } \\
\end{array}$ & $\begin{array}{l}\text { SPE, ultrasonic } \\
\text { extraction, silica } \\
\text { gel cleaning }\end{array}$ & valve & $\begin{array}{l}\text { water: } 0.15- \\
14.08 \mathrm{ng} / \mathrm{l} \text {; soil: } \\
0.06-10.64 \mathrm{ng} / \mathrm{g} \\
\end{array}$ & $\begin{array}{l}\text { RRLC-MS/MS } \\
\text { ESI }\end{array}$ & $\begin{array}{l}\text { Chen et al., } \\
2010\end{array}$ \\
\hline $\begin{array}{l}21 \text { selected } \\
\text { pesticides, phenols } \\
\text { and phthalates }\end{array}$ & water & $\begin{array}{l}\text { SPE, progr. field } \\
\text { extraction system } \\
\text { and Prospect }\end{array}$ & $\begin{array}{l}\text { on-line } \\
\text { SPE-LC }\end{array}$ & $<100 \mathrm{ng} / \mathrm{l}$ & LC-MS, APCI & $\begin{array}{l}\text { López- } \\
\text { Roldán et al., } \\
2004\end{array}$ \\
\hline
\end{tabular}

APCI - atmospheric pressure chemical ionization, ASE - accelerated solvent extraction, ECD - electron capture detector, ESI - electrospray, FS - full scan, HLB - hydrophilic- lipophilic balance, IT - ion trap, LLE - liquid-liquid extraction, LOD - limit of detection, LVI-large volume injection, MAE - microwave assisted extraction, MRM multiple reaction mode, MS - mass spectrometry, MS/MS - tandem mass spectrometry, n.r. - not reported, OCPs organochlorine pesticides, OPPs - organophosphorous pesticides, PAH - polycyclic aromatic hydrocarbon, PBDEs Polybrominated Diphenyl Ethers, PCBs - polychlorinated biphenols, PDMS - polydimethylsiloxane, PPCPs pharmaceuticals and personal care products, PTV - programmed-temperature vaporization (injector), QuEChERS quick, easy, cheap, effective, rugged and safe, SIM - selected ion monitoring, RRLC - rapid resolution liquid chromatography, SBSE - stir bar sorptive extraction, SLE - solid-liquid extraction, SVV - solvent vent valve.

Table 3. An overview of analytical methods for analysis of EDPs with other groups of EDCs

samples. It is surprising, that indoor environment can be a significant source of exposure to some EDCs. Longer residence times and elevated contaminant concentrations in the indoor environment may increase chance of exposure to these contaminants by 1000 -fold compared to outdoor exposure (Hwang et al., 2008).

In GC analysis, the most common injection systems are splitless and mainly PTV (programmed temperature vaporization) injector in solvent vent mode. Helium and exceptionally hydrogen were the most frequently used carrier gases. MS detector in SIM mode is used preferably. Specific and selective detectors as ECD (electron capture detector) 
are also used. LC analysis is usually connected to MS detector with electrospray (ESI), atmospheric pressure chemical ionization (APCI) or atmospheric pressure photoionization (APPI).

For sample preparation, liquid-liquid extraction, solid-liquid extraction and solid-phase extraction (SPE) are the most commonly used techniques. In the present era of "green chemistry", the sampling preparation methods with large amounts of toxic solvents are difficult to justify for multiresidue determinations of EDCs (Serôdio \& Nogueira, 2004). On the other hand, SPE is in some cases tedious, time-consuming and can present some disadvantages, i.e. the breakthrough of large sample volumes or the organic breakdown products that can interfere with the elucidation of unknowns, essentially at the ultra-trace level. The modern approaches are devoted to the development of a single comprehensive method utilizable for a wide variety of compounds with a single extraction in various matrices (Trenholm et al., 2006) or a solventless extraction technique at microscale level (Barrida-Pereira et al., 2010; Peñalver et al., 2003). Solid-phase microextraction (SPME) and stir bar sportive extraction (SBSE) are the often employed representative of microextraction techniques (Barrida-Pereira et al., 2010; Peñalver et al., 2003). The sample preparation approach known as QuEChERS, which stands for "quick, easy, cheap, effective, rugged and safe", firstly introduced by Anastassiades et al., 2003a represents a widely used method of food sample preparation. QuEChERS approach uses acetonitrile for extraction of a 10-15 g homogenized sample followed by salt-out partitioning of the water from the sample using anhydrous $\mathrm{MgSO}_{4}, \mathrm{NaCl}$, and/or buffering agents, and further clean-up using dispersive solid-phase extraction (d-SPE) or disposable pipette extraction (DPX) with anhydrous $\mathrm{MgSO}_{4}$, primary secondary amine (PSA) and/or in combination with $\mathrm{C}_{18}$, graphitized carbon black (GCB) sorbents. It was used for extraction of EDPs from fruit and vegetable matrices (Hrouzková et al., 2011; Húšková et al., 2009a, 2009b, 2010b).

\section{Conventional capillary GC-MS for EDPs analysis}

The contribution of our research group to the EDPs method development was as the first approach focused to the development of the conventional GC-MS method for separation, detection and quantification of EDPs belonging to different chemical classes organochlorines, organophosphates, pyrethroids, dicarboximides, phtalamides, dinitroanilines, pyrazoles and triazinones in apple matrix (Húšková et al., 2009a). The developed method involves the QuEChERS sample preparation method (Anastassiades et al., 2003a) modified according to our needs and resources. Subsequent analysis by conventional capillary GC-MS equipped with a PTV injector and quadrupole bench top mass selective detector. To obtain the low limits of detection (LODs) and limits of quantification (LOQs) required for regulation purposes or lower, selected ion monitoring (SIM) was used. EDPs were separated in $37.8 \mathrm{~min}$.

Two ionization techniques, EI and NCI (with methane as reagent gas) were utilized and compared. Calibration in the NCI mode was performed at the concentration levels from 0.1 to $500 \mu \mathrm{g} / \mathrm{kg}$ (coefficient of determination, $\mathrm{R}^{2}>0.999$ ) and for EI in the range of $5-500 \mu \mathrm{g} / \mathrm{kg}$ 
$\left(\mathrm{R}^{2}>0.99\right)$. From the lowest calibration levels (LCLs) the LODs and LOQs were calculated and are summarized in Table 4. The LODs for all pesticides varied from 0.0019 to $0.94 \mu \mathrm{g} / \mathrm{kg}$ for NCI and from 0.09 to $3.12 \mu \mathrm{g} / \mathrm{kg}$ for EI mode. Repeatability of all measurements, expressed as relative standard deviations of absolute peak areas, met the EU criterion of relative standard deviation, $\mathrm{RSD} \leq 20 \%$.

\begin{tabular}{|c|c|c|c|c|c|c|c|c|c|}
\hline No. & Pesticide & $\begin{array}{c}\mathrm{LCL}^{a} \\
(\mathrm{ng} / \mathrm{mL})\end{array}$ & $\begin{array}{c}\text { RSD } \\
(\%)\end{array}$ & $\begin{array}{c}\text { LOD }^{b} \\
(\mathrm{pg} / \mathrm{mL})\end{array}$ & $\begin{array}{c}\mathrm{LOQ}^{\mathrm{c}} \\
(\mathrm{pg} / \mathrm{mL})\end{array}$ & $\begin{array}{c}\mathrm{LCL}^{a} \\
(\mathrm{ng} / \mathrm{mL})\end{array}$ & $\begin{array}{c}\text { RSD } \\
(\%)\end{array}$ & $\begin{array}{c}\text { LOD }^{b} \\
(\mathrm{ng} / \mathrm{mL})\end{array}$ & $\begin{array}{c}\mathrm{LOQ}^{\mathrm{c}} \\
\text { (ng/mL) }\end{array}$ \\
\hline & & \multicolumn{4}{|c|}{ NCI } & \multicolumn{4}{|c|}{ EI } \\
\hline 1. & trifluralin & 0.1 & 1.7 & 1.90 & 6.32 & 5.0 & 2.0 & 0.10 & 0.33 \\
\hline 2. & hexachlorobenzene & 0.1 & 1.4 & 5.64 & 18.2 & 5.0 & 2.7 & 0.15 & 0.52 \\
\hline 3. & dimethoate & 0.1 & 5.9 & 42.3 & 140 & 5.0 & 7.2 & 0.41 & 1.38 \\
\hline 4. & lindane & 0.1 & 6.5 & 7.52 & 25.2 & 5.0 & 8.5 & 0.75 & 2.50 \\
\hline 5. & metribuzin & 0.1 & 2.3 & 14.1 & 47.4 & 5.0 & 6.9 & 0.28 & 0.94 \\
\hline 6. & chlorpyrifos-methyl & 0.1 & 2.9 & 37.2 & 120 & 5.0 & 6.7 & 0.25 & 0.83 \\
\hline 7. & vinclozolin & 0.1 & 5.0 & 7.71 & 25.2 & 5.0 & 5.5 & 0.68 & 2.27 \\
\hline 8. & heptachlor & 0.5 & 8.5 & 103 & 330 & 5.0 & 5.7 & 0.53 & 1.78 \\
\hline 9. & fenitrothion & 0.1 & 2.6 & 6.80 & 23.4 & 5.0 & 6.4 & 0.22 & 0.74 \\
\hline 10. & malathion & 0.1 & 8.1 & 42.4 & 140 & 5.0 & 9.3 & 0.78 & 2.63 \\
\hline 11. & chlorpyrifos & 0.1 & 4.4 & 5.91 & 19.1 & 10.0 & 6.0 & 0.96 & 3.22 \\
\hline 12. & pendimethalin & 0.1 & 2.4 & 21.4 & 71.2 & 5.0 & 6.9 & 0.30 & 1.02 \\
\hline 13. & captan & 1.0 & 11.1 & 935 & 3114 & 25.0 & 11.2 & 3.12 & 10.4 \\
\hline 14. & folpet & 1.0 & 10.1 & 754 & 2501 & 25.0 & 13.9 & 1.82 & 6.09 \\
\hline 15. & fipronil & 0.1 & 1.7 & 11.4 & 38.7 & 5.0 & 6.1 & 0.13 & 0.45 \\
\hline 16. & methidation & 0.1 & 5.6 & 50.5 & 160 & 5.0 & 6.0 & 0.50 & 1.66 \\
\hline 17. & diazinon & 0.5 & 1.7 & 113 & 351 & 5.0 & 7.5 & 0.14 & 0.36 \\
\hline 18. & endosulfan-alfa & 0.1 & 3.3 & 4.87 & 16.6 & 5.0 & 4.3 & 1.00 & 3.33 \\
\hline 19. & endosulfan-beta & 0.1 & 4.1 & 6.41 & 21.2 & 5.0 & 4.2 & 0.42 & 1.40 \\
\hline 20. & iprodione & 0.1 & 7.3 & 30.5 & 100 & 5.0 & 8.1 & 0.41 & 1.38 \\
\hline 21. & bifenthrin & 0.1 & 1.1 & 20.3 & 66.9 & 5.0 & 4.7 & 0.09 & 0.30 \\
\hline 22. & mirex & 0.5 & 2.4 & 162 & 550 & 5.0 & 6.0 & 0.27 & 0.92 \\
\hline 23. & deltamethrin & 0.5 & 2.5 & 211 & 711 & 25.0 & 6.2 & 2.34 & 7.81 \\
\hline
\end{tabular}

Notes: ${ }^{a}$ LCLs - for some compounds with the highest response it would be possible to go to the lower LCLs; at 0.1 $\mathrm{ng} / \mathrm{mL}$ for NCI and $5 \mathrm{ng} / \mathrm{mL}$ for EI the majority of compounds could be quantified; ${ }^{b} \mathrm{LOD}$ (limit of detection) calculated as 3:1 S/N (signal to noise ratio) from calibration measurements; cLOQ (limit of quantification) - calculated as 10:1 S/N from calibration measurements; RSD - relative standard deviation, other abbreviations - in Tab. 3.

Table 4. The list of the studied endocrine disrupting pesticides in two detection modes (NCI, EI), instrumental LODs ${ }^{b}$ and LOQs $s^{c}$ and RSDs calculated from absolute peak areas of pesticides at the lowest calibration levels (LCLs) (Húšková et al., 2009a). 
To illustrate the matrix phenomena, chromatograms of the target ions of the EDPs analyzed in the real apple sample extract at the concentration level $10 \mathrm{ng} / \mathrm{mL}$ (corresponding to 10 $\mu \mathrm{g} / \mathrm{kg}$ in fruit sample) using both MS ionization techniques in the SIM mode are presented in Fig. 2. In the NCI mode, the influence of sample matrix is not relevant (Schulz, 2004) and

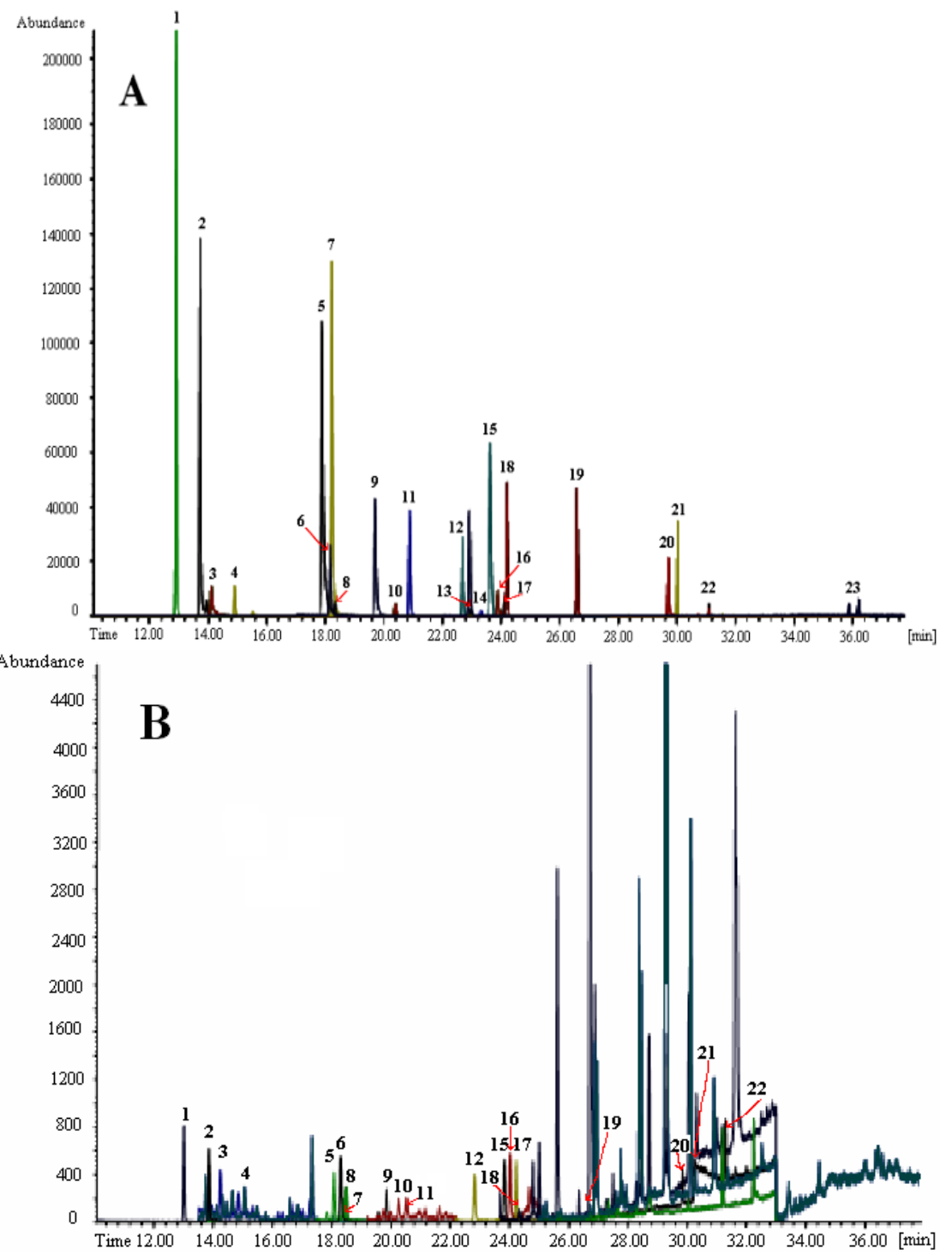

Figure 2. Chromatograms of target ions of endocrine disrupting pesticides analyzed by capillary GCMS in SIM mode in matrix-matched standard solutions at the concentration level $10 \mathrm{ng} / \mathrm{mL}$ (corresponding to $10 \mu \mathrm{g} / \mathrm{kg}$ ): A - NCI mode; B - EI mode (Húšková et al., 2009a). Number of peaks is identical with the number of compounds given in Table 4. 
this fact is evident from Fig. 2A, as a clean chromatogram of the target ions of EDPs without interfering peaks from matrix can be seen. In the EI mode, the pesticides peaks shapes are complicated due to interfering peaks of matrix which creates problems in evaluation of chromatograms. Important negative consequence of interfering peaks from the matrix compounds is a decreased signal to noise ratio in the EI mode. In general, a decreased response (decreased sensitivity) of the pesticides was observed in comparison to the $\mathrm{NCI}$ mode at the same concentration (Fig. 2B).

\section{Fast capillary GC-MS for EDPs analysis}

Numerous ways exist for speeding up the capillary GC separation as it was summarized in reviews (Dömötörová \& Matisová, 2008; Maštovská \& Lehotay, 2003; Matisová \& Dömötörová, 2003). An approach utilizing narrow-bore columns for pesticide residues analysis was elaborated in our research group. Fast separation with narrow-bore capillary columns as a way to reduce the run times provides separation efficiency comparable or even higher than conventional capillary columns (Dömötörová \& Matisová, 2008; Hrouzková \& Matisová, 2011; Matisová \& Dömötörová, 2003).

The benefits of the developed fast GC methods for selected EDPs by our group (Hrouzková et al., 2011; Húšková et al., 2009b, 2010b) provide higher laboratory throughput, reduced GC operating costs, and better analytical precision through replicate analyses compared to conventional GC (Húšková et al., 2009a).

The fast GC-MS method for the determination of 29 pesticides proved or suspected to be endocrine disrupting chemicals (Table 5) was developed and validated by Húšková et al., $2010 \mathrm{~b}$. LOQs in the range of 0.04 to $10 \mu \mathrm{g} / \mathrm{kg}$ for the majority of pesticides were obtained, dicofol, linuron and prochloraz gave LOQs $\leq 21 \mu \mathrm{g} / \mathrm{kg}$ using matrix-matched standards for calibration. The search on different calibration approaches was elaborated. Despite of great efforts in the research of GC amenable pesticide residues analysis the issues are matrix effects and mainly matrix-induced chromatographic response enhancement (Kirchner et al., 2008). Injecting a real sample, the matrix components tend to block active sites in the GC inlet and column, thus reducing losses of susceptible analytes caused by adsorption or degradation on these active sites (Hajšlová \& Zrostlíková, 2003). This phenomenon results in higher analyte signals in matrix-containing, versus matrix-free solutions. Ways to compensate matrix effects include: (i) method of standard addition; (ii) use of isotopically labelled internal standards; (iii) use of matrix-matched standards; and (iv) use of analyte protectants. The most widely used method in laboratories nowadays is the use of matrixmatched standards. This approach is, however, complicated by the fact, that the composition of matrix-matched standard should be as close as possible to the composition of real sample matrix in order to provide good compensation for matrix effects. However, it is difficult to obtain pesticide free matrix for less common commodities and this approach is also laborious. Analyte protectants protect co-injected analytes against degradation, adsorption, or both in the GC system. The novel concept idea was to add analyte protectants (APs) to sample extracts as well as to matrix-free (solvent) standards to induce an even 
response enhancement in both instances (Anastassiades at al., 2003b). Main advantages of using APs should be easier preparation of calibration standards, improvement of trueness of analysis. Húšková et al., 2010b evaluated different calibration approaches based on matrixmatched standardization and application of analyte protectants (3-ethoxy-1,2-propanediol, D-sorbitol, L-gulonic acid $\gamma$-lactone) in apple samples. For illustration, chromatograms of target ions of EDCs pesticides in variety of standard solutions (matrix-matched standard solution, matrix-matched standard solution with APs, neat solvent with APs) analyzed by fast GC-MS in SIM mode at the concentration level of $50 \mathrm{ng} / \mathrm{mL}$ (corresponding to $50 \mu \mathrm{g} / \mathrm{kg}$ ) are presented in Fig. 3. Utilization of pesticide standards in a neat solvent $(\mathrm{MeCN})$ with addition of APs was the simplest approach for routine use. However, it provided higher values of LODs and LOQs, particularly for the most volatile and problematic analytes. Calibration with matrix-matched standards provided the best results compared to other calibration approaches under study in terms of linearity of measurements expressed as $\mathrm{R}^{2}$, instrumental LODs, LOQs and the repeatability of absolute peak area measurements at LCLs expressed as RSDs. Selected validation parameters, LODs, LOQs and LCLs for three types of calibration standards are summarized in Table 5.

Analysis of synthetic sample spiked by EDPs at concentration of $50 \mu \mathrm{g} / \mathrm{kg}$ yielded overestimation and/or underestimation of a number of EDPs using matrix matched standards without/with APs and MeCN with APs with maximal errors up to $22 \%$ (Fig. 4). The degree of overestimation depends on a compound and its concentration and also on the number of injections and the GC system maintenance (periodicity of liner and precolumn change).

Performance of APs as additives for preparation of calibration standards in $\mathrm{MeCN}$ and matrix-matched standards was evaluated by comparison with currently widespread used matrix-matched calibration in fruit and vegetables extracts with the set of selected pesticides utilizing fast GC-MS with narrow-bore columns and QuEChERS sample preparation method (Hercegová et al., 2010). Extracts of fruit and vegetable samples representing different matrix type (apple, pear, cucumber, cauliflower) were subjected to estimation of extract solids to compare amount of co-extracted sample material.

The weight of matrix components was similar for apples and pears. Extract solids of cauliflower had the highest amount of matrix components and the lowest amount of coextractants in cucumber compared to fruit extracts was obtained. To search the matrix effects intensity, the measurements of MeCN extracts in full scan mode and SIM monitoring for all matrices with the known concentration of pesticide residues $(50 \mu \mathrm{g} / \mathrm{kg})$ were performed. An acceptable agreement of quantified pesticide residues concentrations with spiked fortified concentration $(50 \mu \mathrm{g} / \mathrm{kg})$ was obtained utilizing matrix-matched calibration standards and matrix-matched standards with addition of APs in all studied matrices. Standards in a neat solvent $(\mathrm{MeCN})$ with the addition of APs yielded overestimation for a number of pesticides under study. The overestimation was shown to be matrix dependent and influenced by the number of injections performed. In the case of $\mathrm{MeCN}$ standards with APs and quantification using absolute peak areas and normalized areas to internal standards (triphenylphosphate, heptachlor), overestimation of the results for majority the 

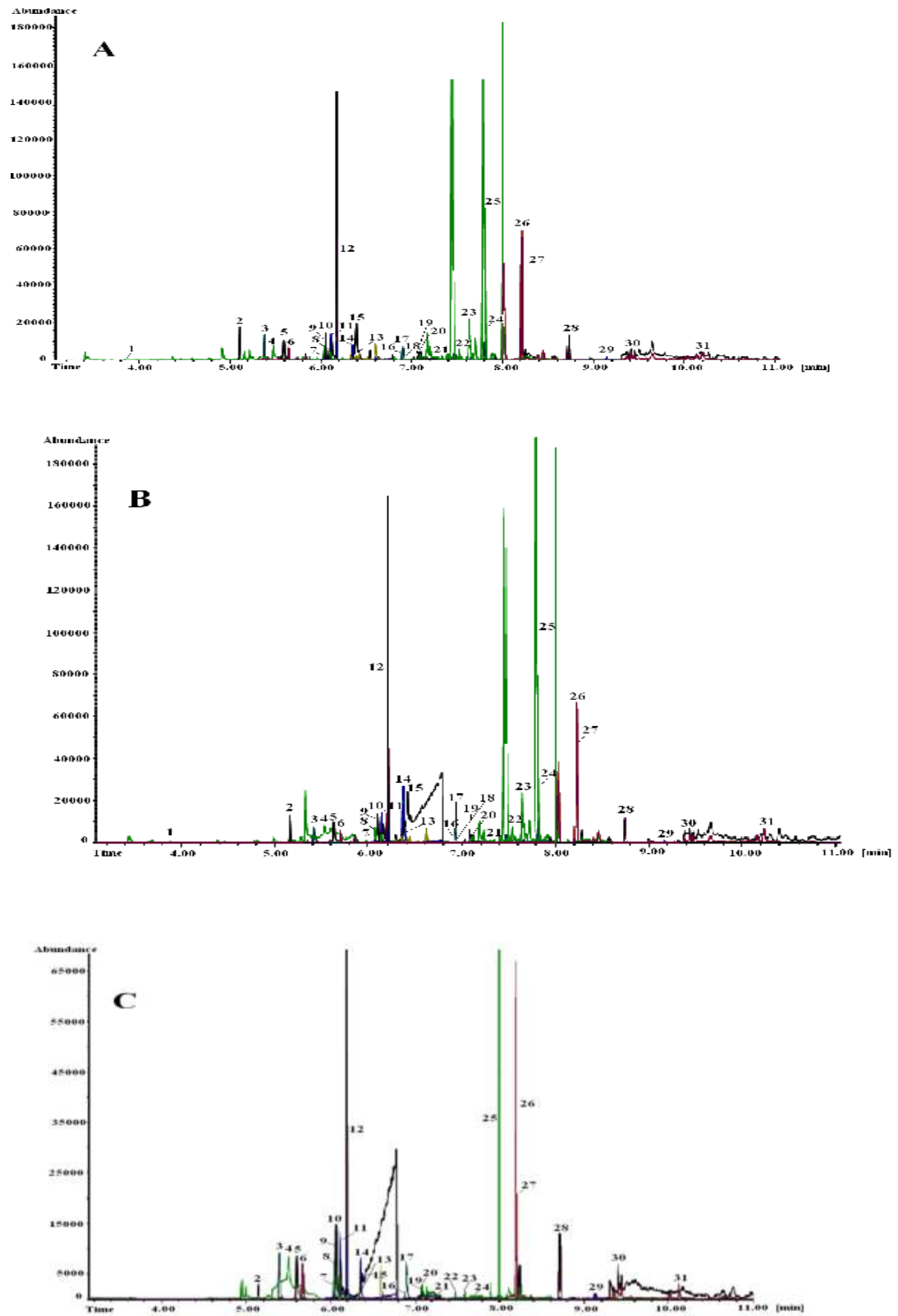

Note: numbering of peaks is identical with the number of compounds given in Table 5, as well as abbreviations.

Figure 3. Chromatograms of target ions of EDCs pesticide in various standard solutions $(50 \mathrm{ng} / \mathrm{mL})$ analyzed by fast GC-MS in SIM mode: A - matrix-matched standard solution without APs; B- matrixmatched standard solution with APs; C - MeCN standard solution with APs (Húšková et al., 2010b). 


\begin{tabular}{|c|c|c|c|c|c|c|c|c|c|c|}
\hline \multirow[b]{2}{*}{ No } & \multirow[b]{2}{*}{ Pesticide } & \multicolumn{3}{|c|}{ Matrix } & \multicolumn{3}{|c|}{ Matrix + APs } & \multicolumn{3}{|c|}{$\mathrm{MeCN}+\mathrm{APs}$} \\
\hline & & $\begin{array}{c}\text { LCL } \\
\mathrm{ng} / \mathrm{mL}\end{array}$ & $\begin{array}{c}\mathrm{LOD} \\
\mathrm{ng} / \mathrm{mL}\end{array}$ & $\begin{array}{c}\mathrm{LOQ} \\
\mathrm{ng} / \mathrm{mL}\end{array}$ & $\begin{array}{c}\mathrm{LCL} \\
\mathrm{ng} / \mathrm{mL}\end{array}$ & $\begin{array}{c}\mathrm{LOD} \\
\mathrm{ng} / \mathrm{mL}\end{array}$ & $\begin{array}{c}\text { LOQ } \\
\mathrm{ng} / \mathrm{mL}\end{array}$ & $\begin{array}{c}\mathrm{LCL} \\
\mathrm{ng} / \mathrm{mL}\end{array}$ & $\begin{array}{l}\mathrm{LOD} \\
\mathrm{ng} / \mathrm{mL}\end{array}$ & $\begin{array}{c}\mathrm{LOQ} \\
\mathrm{ng} / \mathrm{mL}\end{array}$ \\
\hline 1 & diuron & 10 & 2.63 & 8.77 & 10 & 3.59 & 11.97 & 100 & 14.37 & 57.86 \\
\hline 2 & trifluralin & 1 & 0.07 & 0.24 & 1 & 0.10 & 0.32 & 1 & 0.12 & 0.39 \\
\hline 3 & hexachlorbenzen & 1 & 0.02 & 0.08 & 1 & 0.03 & 0.09 & 1 & 0.03 & 0.11 \\
\hline 4 & dimethoate & 1 & 0.16 & 0.53 & 1 & 0.22 & 0.73 & 5 & 2.27 & 7.49 \\
\hline 5 & atrazine & 1 & 0.85 & 2.83 & 1 & 1.16 & 3.87 & 1 & 1.41 & 4.70 \\
\hline 6 & lindan & 1 & 0.52 & 1.73 & 1 & 0.71 & 2.37 & 1 & 0.80 & 2.67 \\
\hline 7 & acetochlor & 1 & 0.77 & 2.57 & 1 & 1.05 & 3.51 & 1 & 1.19 & 3.96 \\
\hline 8 & $\begin{array}{l}\text { chlorpyrifos- } \\
\text { methyl }\end{array}$ & 1 & 0.08 & 0.27 & 1 & 0.06 & 0.20 & 1 & 0.12 & 0.41 \\
\hline 9 & vinclozolin & 1 & 0.29 & 0.97 & 1 & 0.22 & 0.73 & 5 & 3.45 & 11.38 \\
\hline 10 & alachlor & 1 & 0.09 & 0.30 & 1 & 0.07 & 0.23 & 1 & 0.13 & 0.44 \\
\hline 11 & metribuzin & 1 & 0.10 & 0.33 & 1 & 0.08 & 0.25 & 1 & 0.15 & 0.49 \\
\hline 12 & heptachlor & \multicolumn{9}{|c|}{ Internal standard } \\
\hline 13 & dicofol & 10 & 3.56 & 11.87 & 10 & 4.80 & 16.01 & 10 & 5.21 & 17.37 \\
\hline 14 & malathion & 1 & 0.34 & 1.13 & 1 & 0.27 & 0.89 & 1 & 0.60 & 2.00 \\
\hline 15 & linuron & 10 & 6.32 & 21.07 & 10 & 9.20 & 30.68 & 50 & 18.15 & 66.07 \\
\hline 16 & diazinon & 1 & 0.09 & 0.28 & 1 & 0.13 & 0.44 & 1 & 0.16 & 0.53 \\
\hline 17 & procymidone & 1 & 0.27 & 0.90 & 1 & 0.39 & 1.31 & 1 & 0.48 & 1.59 \\
\hline 18 & folpet & 10 & 1.05 & 3.50 & 10 & 1.53 & 5.10 & 100 & 21.54 & 75.17 \\
\hline 19 & chlordane & 1 & 0.10 & 0.32 & 1 & 0.15 & 0.49 & 1 & 0.25 & 0.87 \\
\hline 20 & endosulfan-alfa & 1 & 0.46 & 1.53 & 1 & 0.32 & 1.07 & 5 & 2.72 & 9.41 \\
\hline 21 & myclobutanil & 1 & 0.07 & 0.22 & 1 & 0.05 & 0.16 & 1 & 0.11 & 0.37 \\
\hline 22 & nitrofen & 5 & 1.09 & 3.62 & 5 & 0.76 & 2.54 & 10 & 1.92 & 6.42 \\
\hline 23 & endosulfan-beta & 1 & 0.01 & 0.04 & 1 & 0.02 & 0.05 & 5 & 1.02 & 3.69 \\
\hline 24 & chlordecone & 10 & 0.91 & 3.03 & 10 & 0.61 & 2.02 & 50 & 3.61 & 12.82 \\
\hline 25 & TPP & \multicolumn{9}{|c|}{ Internal standard } \\
\hline 26 & bifenthrin & 1 & 0.02 & 0.08 & 1 & 0.03 & 0.11 & 1 & 0.04 & 0.12 \\
\hline 27 & iprodione & 1 & 0.10 & 0.33 & 1 & 0.17 & 0.55 & 1 & 0.16 & 0.53 \\
\hline 28 & mirex & 1 & 0.11 & 0.32 & 1 & 0.18 & 0.61 & 1 & 0.26 & 0.87 \\
\hline 29 & prochloraz & 10 & 5.37 & 17.90 & 10 & 3.21 & 10.70 & 50 & 7.83 & 26.12 \\
\hline 30 & cypermethrin & 5 & 2.05 & 6.83 & 5 & 2.87 & 9.56 & 5 & 3.24 & 10.79 \\
\hline 31 & deltamethrin & 1 & 0.07 & 0.24 & 1 & 0.06 & 0.20 & 5 & 1.11 & 3.88 \\
\hline
\end{tabular}

Notes. ${ }^{\text {a }}$ calculated as 3:1 S/N ratio, ${ }^{b}$ calculated as 10:1 S/N ratio, APs - analyte protectants; MeCN - acetonitrile; TPP triphenylphosphate; other abbreviations in Tab. 3, 4 .

Table 5. Instrumental LODs, LOQs / LODsa ${ }^{\mathrm{a}}$ LOQs ${ }^{\mathrm{b}}$ for all types of calibration standards (Húšková et al., 2010b). 


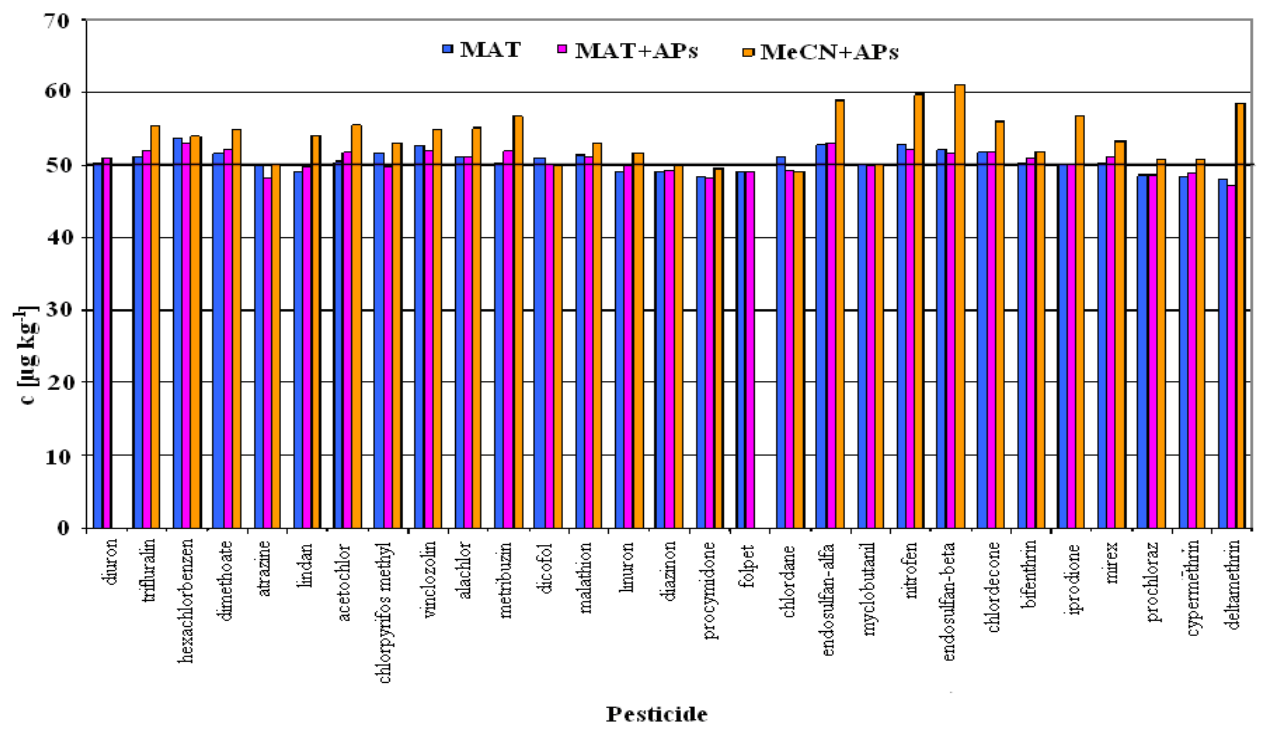

Figure 4. Graph of calculated concentrations of endocrine disrupting pesticides in synthetic sample using matrix-matched standards without/with APs and MeCN + APs vs. the expected $50 \mu \mathrm{g} / \mathrm{kg}$ concentration (Húšková et al., 2010b). For each of matrix-matched types of calibration standards the QuEChERS extract of apples was used. Six GC-MS measurements were performed for synthetic sample and relevant calibration standards. Abbreviations in Table 5.

tested pesticides in all matrices was observed. The maximal value of error of determination of average concentration was found to be $39.8 \%$. In some cases also underestimation of quantity was observed.

The fast GC set-up using narrow-bore column (0.15 mm I.D.) in combination with MS detector in NCI mode was introduced by Húšková et al., 2009b and compared to fast GCMS with EI. Multi-residue method of 25 EDPs belonging to different groups (organochlorines, organophosphates, pyrethroids, dicarboximides, 2,6-dinitroanilines, triazinones, substituted ureas, phthalamides, cyclodienes, triazoles, imidazoles), varying in polarity, volatility and other physicochemical properties from non-fatty fruit and vegetable matrices based on fast GC with quadrupole NCI-MS was developed. The method LOQ was found to be $5 \mu \mathrm{g} / \mathrm{kg}$ (except for folpet, chlordecone, endosulfan-alfa and endosulfan-beta) in EI mode, $1 \mu \mathrm{g} / \mathrm{kg}$ in NCI mode for 12 compounds under study and 0.1 $\mu \mathrm{g} / \mathrm{kg}$ for 13 compounds. The EU criterion concerning recovery rates was fulfilled at these concentration levels. The harmful effect of EDPs is relevant at very low concentrations, so the use of NCI-MS was shown to be an effective tool to decrease LOQs 5-50 times compared to EI mode. Changing the universal MS detection in EI mode by NCI, the selectivity was increased, and the measured sensitivity of the selected analytes was enhanced for a variety of active EDPs with the adverse effect on wildlife or human system. Comparison of relevant validation parameters is given in Tab. 6 . 


\begin{tabular}{|l|c|c|}
\hline \multicolumn{1}{|c|}{ Method / Results } & GC-NCI-MS & GC-EI-MS \\
\hline LCLs & $0.01,0.05 \mu \mathrm{gg} / \mathrm{kg}$ & $1 \mu \mathrm{g} / \mathrm{kg}$ \\
$\mathrm{R}^{2}$ & $0.9936-1.0000$ & $0.9882-0.9999$ \\
LODs & $0.15-88.82 \mathrm{ng} / \mathrm{kg}$ & $0.01-6.32 \mu \mathrm{\mu g} / \mathrm{kg}$ \\
LOQs & $0.52-291.35 \mathrm{ng} / \mathrm{kg}$ & $0.04-21.07 \mu \mathrm{g} / \mathrm{kg}$ \\
\hline
\end{tabular}

Notes: $\mathrm{R}^{2}$ - coefficient of determination, other abbreviations in Tab. 3, 4.

Table 6. Comparison of validation parameters for NCI vs. EI mode of GC-MS analysis of pesticide residues in apple extract.

\section{Chemmometric approach}

Chemmometric study of pesticide signals in two MS modes answers two basic questions on $\mathrm{NCI}$ and EI signals proportionality and on the possibility of simultaneous evaluation of signals (Húšková et al., 2009a).

The mutual proportionality was searched by regression analysis. At first the regression coefficients were calculated for all 23 EDPs (Table 4) under calibration conditions described by Húšková et al., 2009a for two MS modes using linear models defined as signal vs. concentration of standards. For each pesticide the measurement sensitivity was found by the slopes $b_{\mathrm{NCI}}$ and $b_{E I}$ concerning NCI and EI mode, respectively, including their corresponding standard deviations. Then further regression model was set: $b_{E I}=a+b . b_{N C I}$; in this case $b_{E I}$ and $b_{\mathrm{NCI}}$ were used as the regression variables. The resulting dependence is plotted in Fig.5.

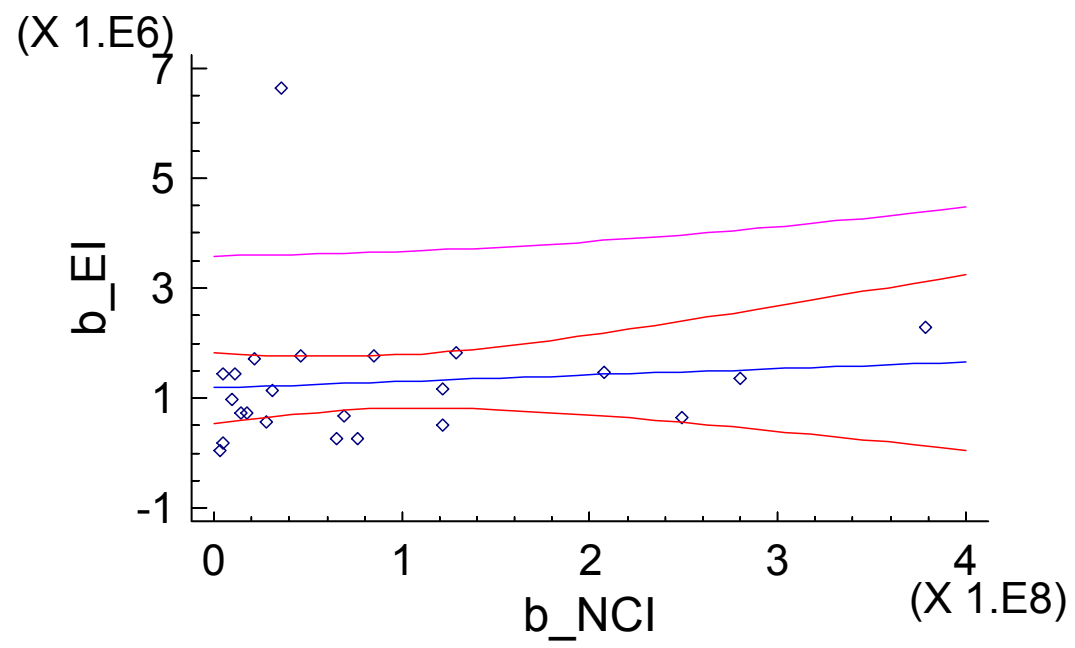

Figure 5. Ordinary least squares linear regression for the model $b_{E I}=a+b . b_{N C I}$ and 23 endocrine disrupting pesticides numbered in Table 4 . The points ranked by the increased value along the $b_{\mathrm{NCI}}$ axis (b_NCI in figure) correspond to the pesticides: $14,13,22,8,17,23,4,16,20,3,21,6,19,11,18,12,10,9,15,2,7,5$, and 1. In addition to regression straight-line the regression and prediction confidence bands ( $90 \%$ probability) are plotted (the lower prediction band was cut off by the choice of the values on vertical axis). 
Two influential points were observed: pesticide number 21 (bifenthrin) exhibited extraordinary large sensitivity in EI mode and can be considered as outlier and pesticide number 1 (trifluralin), which exhibits extreme NCI sensitivity. Found slope value $a_{1}$ was relatively small compared to the corresponding standard deviation sal, therefore mutual dependence of the EI and NCI signals appeared insignificant.

When pesticide number 21 was excluded from regression it was found for the slope $a_{1}=$ 0.00249 and $s_{a 1}=0.00125$, which means an insignificant dependence at $95 \%$ probability level but significant one at $90 \%$ probability. However, a fully correct way of regression is performed when the error of both regression variables, $b_{E I}$ and $b_{N C I}$, are considered, since both the EI as well as NCI signals are random variables. Such a calculation provides bivariate least squares method (Mocák et al., 2003), which is a variant of weighted Deming regression, where each regression point is computed from four values - two variables and their standard deviations. The found regression equation for all 23 EDPs was $b_{\mathrm{NCI}}=1.330 \times 10^{5}$ $+0.00593 b_{E I}$ with $s_{a 1}=0.00195$ and $s_{a 0}=1.012 \times 10^{5}$, which signifies a significant slope and an insignificant intercept at $95 \%$ probability. The correlation coefficient was $r=0.5197$, which is significant when compared to the critical value $r_{\text {crit }}=0.4132$. The same final results concerning significance of the slope and intercept were found when 22 pesticides were studied (without number 21) with a slightly larger correlation coefficient, $r=0.5566$. It can be concluded that the sensitivities of the EI and NCI signals are significantly mutually dependent despite the imperfect proportionality in case of some pesticides.

The question on the possibility of simultaneous evaluation of signals was studied by the principal component analysis, PCA, which is a multivariate data analysis method (Sharma, 1996) capable to express the collective effect of the EI and NCI signal sensitivities. In this method, new variables, the principal components are calculated by optimal linear combination of original variables. As it is obvious in this method, the original variables $b_{N C I}$ and $b_{E I}$ were standardized by the corresponding mean subtraction and division by the corresponding standard deviation. The calculated PCA plot PC2 vs. PC1 is depicted in Fig.6. The first principal component, PC1, generally expresses the conjoint effect of all original variables, which means the common sensitivity in this study since it was found to be a positive linear combination of $b_{\mathrm{NCI}}$ and $b_{E I}$. The second principal component, PC2, expresses here the relative magnitude of the sensitivities in the EI mode (positive PC2 values) and the NCI mode (negative PC2 values). From the position of the pesticide samples in the PC2 PC1 plane it is possible to understand several observed effects. The lowest PC1 values mean the smallest sensitivities, which exhibit pesticides 14 and 13; on the contrary, the highest PC1 values mean the largest sensitivities, exhibited by pesticides 1 and 21, then by 5,2 and 7 in a smaller extent. A high PC2 value means extraordinary large EI sensitivity, a low (negative) PC2 value means extraordinary large NCI sensitivity. The occurrence of negative PC2 as well as PC1 values follows from the PCA data processing since the original variable values less than the mean are negative after performed standardization. It is clearly seen from Fig. 6 that relatively high EI signals (in decreasing order) have pesticides 21, 16, 22, 17, $6,8,3,12,23$, and 4 (all with PC2>0.15); relatively high NCI signals (in decreasing order) have pesticides $1,7,5,2,9,10,18,19$, and 11 (all with $\mathrm{PC} 2<0.15$ ). Balanced (but low) NCI 
and EI sensitivities exhibit pesticides 14, 13, 15, and 20. In general, the found LOD and LOQ values are inversely proportional to the observed sensitivities, e.g. the lowest LOD in the NCI mode has pesticide 1 and pesticide 21 in the EI mode.

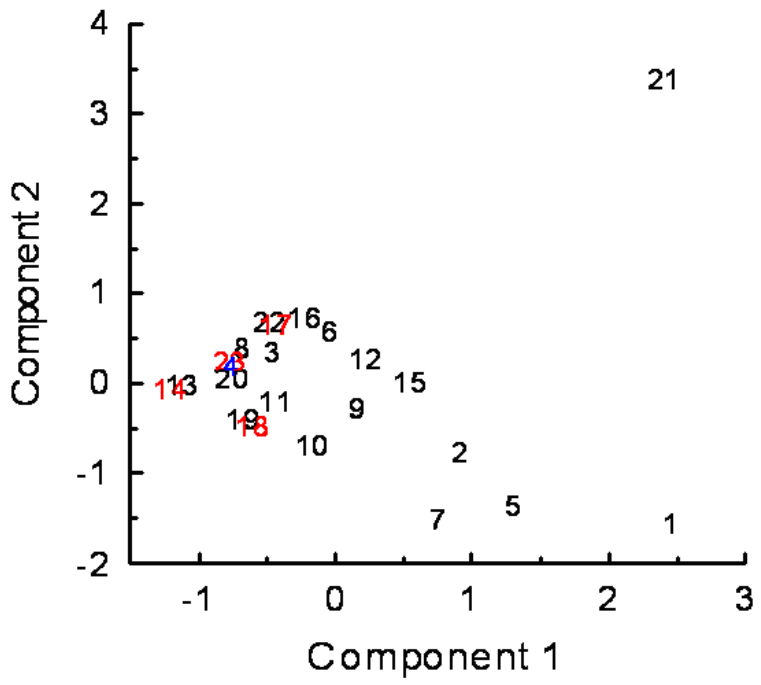

Figure 6. Dependence of principal components (PC) in principal component analysis. Component $1=$ PC1, component $2=\mathrm{PC} 2$. Numbers in the figure denote endocrine disrupting pesticides listed in Table 4. First and second component contain $54.5 \%$ and $45.5 \%$ of the total variability of data.

\section{Real-life EDPs analysis}

The applicability of the developed and validated methods was demonstrated by real-life samples analyses showing that developed GC-MS methods in both, conventional and fast, arrangements are suitable for the analysis of EDPs at low concentration levels in a variety of fruit and vegetable samples.

Positive findings of EDPs in real samples determined by fast GC-MS were reported by Húšková et al., 2010b, particularly malathion in orange sample and iprodione in lettuce, strawberry, and plum. Matrix-matched standards (apple matrix) without/with APs and $\mathrm{MeCN}$ standards with APs were used for quantification. Concentration of quantified EDPs was in the range of $41-246 \mu \mathrm{g} / \mathrm{kg}$.

Utilization of APs and its comparison with matrix-matched calibration standards was performed in the analysis of real samples with pesticide residues (Hercegová et al., 2010). Quantified concentrations of pesticide residues were lower than the MRLs for the corresponding matrix. Good match between results obtained using both calibration approaches was reached.

To show the potential of fast GC for the utilization in the ultratrace analysis of pesticide residues with endocrine disruption behaviour, the survey of EDPs in non-fatty food was 
published by Hrouzková et al., 2011. An important objective was to assess the occurrence of pesticides from different chemical classes suspected or known to act as endocrine disrupters in fruit and vegetable samples available on the market in Slovakia. Thirty-four samples of 20 different commodities were analyzed. Twenty-one compounds at concentrations in the range of $0.003-2.14 \mathrm{mg} / \mathrm{kg}$ were detected in 28 positive samples. The MRL value was exceeded in the case of dimethoate (peachA). In the case of fenitrotion (peach $\mathrm{B}$ ) the determined concentration was at the MRL level. Seven samples contained residues of three or more pesticides.

\section{Conclusions}

EDPs are known as a class of EDCs which have xenobiotic origin. They mimic or inhibit the natural action of the endocrine system in wildlife and humans, such as synthesis, secretion, transport, and binding. The chapter was devoted to the significance and importance of endocrine disrupters investigation, to the evolution and current state of EDPs list creation. The approach of regulatory agencies in European Union, in United States and further to the EDCs/EDPs problem solutions was discussed.

For the identification and quantification chromatographic methods hyphenated with massspectrometric detection provide the excellent sensitivity and precision. These methods generally comprise also preconcentration step based on the extraction of EDPs.

The main part of the chapter was devoted to the contribution in GC-MS methods development for EDPs with the utilization of conventional and fast GC. The search on the different calibration approaches based on the matrix-matched standardization, the application of analyte protectants and the influence of different matrices with differing amounts of co-extractants was studied with the aim to eliminate the adverse effects caused by matrix interferences. The combination of fast GC separation and selective MS detection with NCI resulted to selectivity enhancement and decrease of the limits of quantification.

For EDPs residues analysis ultrasensitive analytical methods are required and there is still the need to improve the performance and ruggedness of analyses. Despite the progress in the analytical instrumentation development, for most of substances there is continuous need to employ the extraction and preconcentration.

Identification and determination of endocrine disrupting pesticides is a relevant research trend and a progress of analytical methods as a base for necessary changes in regulations of the quality of food and environment in the future is expected.

\section{Author details}

Svetlana Hrouzková and Eva Matisová

Institute of Analytical Chemistry, Faculty of Chemical and Food Technology,

Slovak University of Technology in Bratislava, Slovak Republic 


\section{Acknowledgement}

This work was supported by the Scientific Grant Agency VEGA project No. 1/0647/11.

\section{References}

Alder, L.; Greulich, K.; Günther, K.; Kempe, G.; Bärbel, V. \& Vieth, B. (2006). Residue analysis of 500 high priority pesticides: Better by GC-MS or LC-MS/MS? Mass Spectrometry Reviews, Vol.25, No.6, (November-December 2006), pp. 838-865, ISSN 02777037

Almeida, C.; Serôdio, P.; Florencio, M.H. \& Nogueira, J.M.F. (2007). New strategies to screen for endocrine-disrupting chemicals in the Portuguese marine environment utilizing large volume injection-capillary gas chromatography-mass spectrometry combined with retention time locking libraries (LVI-GC-MS-RTL). Analytical and Bioanalytical Chemistry, Vol.87, No.7, (April 2007), pp. 2569-2583, ISSN 1618-2642

Anastassiades, M.; Lehotay, S.J.; Štajnbaher, D. \& Schenck, F.J. (2003)a. Fast and easy multiresidue method employing acetonitrile extraction/partitioning and "dispersive solid-phase extraction" for the determination of pesticide residues in produce. Journal of AOAC International, Vol.86, No.2, (March 2003), pp. 412-431, ISSN 1060-3271

Anastassiades, M.; Maštovská, K. \& Lehotay, S.J. (2003)b. Evaluation of analyte protectants to improve gas chromatographic analysis of pesticides. Journal of Chromatography $A$, Vol.1015, No.1-2, (October 2003), pp. 163-184, ISSN 0021-9673

Barriada-Pereira, M.; Serodio, P.; Gonzalez-Castro, M.J. \& Nogueira, J.M.F. (2010). Determination of organochlorine pesticides in vegetable matrices by stir bar sorptive extraction with liquid desorption and large volume injection-gas chromatography-mass spectrometry towards compliance with European Union directives. Journal of Chromatography A, Vol.1217, No.1, (January 2010), pp. 119-126, ISSN 0021-9673

Baugros, J.B.; Giroud, B.; Dessalces, G.; Grenier-Loustalot, M.F. \& Cren-Olivé, C. (2008). Multiresidue analytical methods for the ultra-trace quantification of 33 priority substances present in the list of REACH in real water samples. Analytica Chimica Acta, Vol.607, No.2, (Jan. 2008), pp. 191-203, ISSN 0003-2670

Bezbaruah, A.N. \& Kalita, H. (2010). Sensors and biosensors for endocrine disrupting chemicals: State-of-the-art and future trends. In: Treatment of Micropollutants in Water and Wastewater, Ed: Virkutyte, J., Jegatheesan, V. \& Varma, R. S. pp. 93-127, IWA Publishing, ISBN 9781843393160, London, UK

Brossa, L.; Marcé, R.M.; Borrull, E. \& Pocurull, E. (2002). Application of on-line solid-phase extraction-gas chromatography-mass spectrometry to the determination of endocrine disruptors in water samples. Journal of Chromatography A, Vol.963, No.1-2, (July 2002), pp. 287-294, ISSN 0021-9673

Brossa, L.; Marcé, R.M.; Borrull, F. \& Pocurull, E. (2003). Determination of endocrinedisrupting compounds in water samples by on-line solid-phase extractionprogrammed-temperature vaporisation-gas chromatography-mass spectrometry. Journal of Chromatography A, Vol.998, No.1-2, (May 2003), pp. 41-50, ISSN 0021-9673 
Chang, H.S.; Choo, K.H.; Lee, B. \& Choi, S.J. (2009). The methods of identification, analysis, and removal of endocrine disrupting compounds (EDCs) in water. Journal of Hazardous Materials, Vol.172, No.1, (December 2009), pp. 1-12, ISSN 0304-3894

Chen, F.; Ying, G.G.; Yang, J.F.; Zhao, J.L. \& Wang, L. (2010). Rapid resolution liquid chromatography-tandem mass spectrometry method for the determination of endocrine disrupting chemicals (EDCs), pharmaceuticals and personal care products (PPCPs) in wastewater irrigated soils. Journal of Environmental Science and Health B, Vol.45, No.7, (October 2010), pp. 682-693, ISSN 0360-1234

Colborn, T.; vom Saal, F.S. \& Soto, A.M. (1993). Developmental effects of endocrinedisrupting chemicals in wildlife and humans. Environmental Health Perspectives, Vol.101, No.5, (October 1993), pp. 378-384, ISSN 0091-6765

Colborn, T.; Dumanoski, D. \& Myers, J.P. (1996). Our Stolen Future. Penguin Books, ISBN 0525-93982-2, New York

Colborn, T. (2012). TEDX - The Endocrine Disruption Exchange, Endocrine Disruption Fact Sheet, Date of Access Feb. 2012, Available from:

http://www.endocrinedisruption.com/files/EDFactSheet11-7-11.pdf.

Comerton, A.M.; Andrews, R.C. \& Bagley, D.M. (2009). Practical overview of analytical methods for endocrine-disrupting compounds, pharmaceuticals and personal care products in water and wastewater. Philosophical Transactions of the Royal Society A, Vol.367, No.1904, (October 2009), pp. 3923-3939, ISSN 1471-2962

Diamanti-Kandarakis, E.; Bourguignon, J.P; Giudice, L.C.; Hauser, R.; Prins, G.S.; Soto, A. M.; Zoeller, R.T. \& Gore, A.C. (2009). Endocrine-Disrupting Chemicals: An Endocrine Society Scientific Statement. Endocrine Reviews, Vol.30, No.4, (June 2009), pp. 293-342, ISSN 1945-7189

Dömötörová, M. \& Matisová, E. (2008). Fast gas chromatography for pesticide residues analysis. Journal of Chromatography A, Vol.1207, No.1-2, (April 2008), pp. 281-294, ISSN 0021-9673

Dostálek, J.; Přibyl, J.; Homola, J. \& Skládal, P. (2007). Multichannel SPR biosensor for detection of endocrine disrupting compounds. Analytical and Bioanalytical Chemistry, Vol.389, No.6, (November 2007), pp. 1841-1847, ISSN 1618-2642

Durán-Alvarez, J.C.; Becerill-Bravo, E.; Castro, V.S.; Jiménez, B. \& Gibson, R. (2009). The analysis of a group of acidic pharmaceuticals, carbamazepine, and potential endocrine disrupting compounds in wastewater irrigated soils by gas chromatography-mass spectrometry. Talanta, Vol.78, No.3, (May 2009), pp. 1159-1166, ISSN 0039-9140

Dybing, E. (2006). Endocrine disrupters - a role in human health?, In. Endocrine Disrupters, Grotmol, T.; Bernhof, A.; Eriksen, G.S.; pp. 9-13, The Norwegian Academy of Science and Letters, ISBN 978-82-7099-437-3, Oslo, Norway

European Commission [EC], Endocrine disrupters website. (Date of revision: November $\left.16^{\text {th }}, 2011\right)$. In: Definitions. What are endocrine disrupters? Date of access: Ferbruary $8^{\text {th }}$, 2011. Available from:

http://ec.europa.eu/environment/endocrine/definitions/endodis_en.html

EC document (1999). Commission of the European Communities: Community Strategy for Endocrine Disrupters 706 
EC document (2006). Stockholm Convention on Persistent Organic Pollutants. Official Journal of the European Union, Vol.L209, (July 2006), pp. 3-29, ISSN 1725-2423

EC document (2007) Commission of the European Communities: Commission staff working document on the implementation of the "Community Strategy for Endocrine Disrupters 1635

Fang, H.; Tong, W.; Shi, L.M.; Blair, R.; Perkins, R.; Branham, W.; Hass, B.S.; Xie, Q.; Dial, S.L.; Moland, C.L. \& Sheehan, D.M. (2001). Structure-activity relationships for a large diverse set of natural, synthetic, and environmental estrogens. Chemical Research in Toxicology, Vol.14, No.3, (March 2001), pp. 280-294, ISSN 0893-228X

Fatoki, O.S. \& Awofolu, R.O. (2003). Methods for selective determination of persistent organochlorine pesticide residues in water and sediments by capillary gas chromatography and electron-capture detection. Journal of Chromatography A, Vol.983, No.1-2, (January 2005), pp. 225-236, ISSN 0021-9673

Hajšlová, J. \& Zrostlíková, J. (2003). Matrix effects in (ultra)trace analysis of pesticide residues in food and biotic matrices. Journal of Chromatography A, Vol.1000, No.1-2, (June 2003), pp. 181-197, ISSN 0021-9673

Hercegová, A.; Húšková, R. \& Matisová, E. (2010). Evaluation of different calibration approaches in pesticide residues analysis in non-fatty food using fast GC-MS. International Journal of Environmental Analytical Chemistry, Vol.90, No.3-6 SI, (March 2010), pp. 188-204, ISSN 0306-7319

Holland, P.T. (2003). Analysis of endocrine active substances in food and the environment. Pure and Applied Chemistry, Vol.75, No.11-12, (December 2003), pp. 1843-1857, ISSN 0033-4545

Hrouzková, S. \& Matisová, E. (2011). Fast Gas Chromatography and Its Use in Pesticide Residues Analysis. In: Pesticides - Strategies for Pesticides Analysis, Stoytcheva, M., (Ed.), pp. 131-154, InTech, ISBN 978-953-307-460-3, Croatia

Hrouzková, S.; Matisová, E.; Andraščíková, M.; Horváth, M.; Húšková, R. \& Ďurčanská, J. (2011). Survey of low-level endocrine disrupting pesticides in food matrices in Slovakia.0 International Journal of Environmental Analytical Chemistry, iFirst (Available online: November 2011) DOI:10.1080/03067319.2011.592944, ISSN 1029-0397 (Online)

Húšková, R.; Matisová, E.; Švorc, L.; Mocák, J. \& Kirchner, M. (2009)a. Comparison of negative chemical ionization and electron impact ionization in gas chromatographymass spectrometry of endocrine disrupting pesticides. Journal of Chromatography A, Vol.1216, No.24, (June 2009), pp. 4927-4932, ISSN 0021-9673

Húšková, R.; Matisová, E.; Hrouzková, S. \& Švorc, L. (2009)b. Analysis of pesticide residues by fast GC in combination with negative chemical ionization mass spectrometry. Journal of Chromatography A, Vol.1216, No.35, (August 2009), pp. 6326-6334, ISSN 0021-9673

Húšková, R.; Matisová, E. \& Hrouzková, S. (2010)a. Mass spectrometry with negative chemical ionization and its use in GC-MS analysis of organic pollutants. Chemické Listy, Vol.104, No.10, (October 2010), pp. 913-920, ISSN 0009-2770

Húšková, R.; Matisová, E.; Ondreková, S. \& Ďurčanská, J. (2010)b. Fast GC-MS of endocrine disrupting chemicals. International Journal of Environmental Analytical Chemistry, Vol.90, No.3-6 SI, (March 2010), pp. 173-187, ISSN 0306-7319 
Hwang, H.M.; Park, E.K.; Young, T.M. \& Hammock, B.D. (2008). Occurrence of endocrinedisrupting chemicals in indoor dust. Science of the Total Environment, Vol.404, No.1, (October 2008), pp. 26-35, ISSN 0048-9697

Jobling, S. (1998). Natural and anthropogenic environmental oestrogens: the scientific basis for risk assessment. Review of suggested testing methods for endocrine-disrupting chemicals. IUPAC Pure and Applied Chemistry, Vol. 70, No. 9, (August 1998), pp. 18051827, ISSN 0033-4545

Jobling, S. (2004). Endocrine disruption in wild fish. IUPAC Pure and Applied Chemistry, Vol. 75, No. 11-12, (November - December 2004), pp. 2219-2234, ISSN 0033-4545

Kirchner, M.; Húšková, R.; Matisová, E. \& Mocák, J. (2008). Fast gas chromatography for pesticide residues analysis using analyte protectants. Journal of Chromatography $A$, Vol.1186, No.1-2, (April 2008), pp. 271-280, ISSN 0021-9673

LaFleur, A.D. \& Schug, K.A. (2011). A review of separation methods for the determination of estrogens and plastics-derived estrogen mimics from aqueous systems. Analytica Chimica Acta, Vol.696, No.1-2, (June 2011), pp.6-26, ISSN 00032670

Lagana, A.; Bacaloni, A.; de Leva, I.; Faberi, A.; Fago, G. \& Marino, A. (2004). Analytical methodologies for determining the occurrence of endocrine disrupting chemicals in sewage treatment plants and natural waters. Analytica Chimica Acta, Vol.501, No.1, (January 2004), pp. 79-88, ISSN 00032670

Lintelmann, J.; Katayama, A.; Kurihara, N.; Shore, L. \& Wenzel, A. (2003). Endocrine disruptors in the environment. Pure and Applied Chemistry, Vol.75, No.5, (May 2003), pp. 631-681, ISSN 0033-4545

Lopez-Espinosa, M.-J.; Granada, A.; Carreno, J.; Salvatierra, M.; Olea-Serrano, F. \& Olea, N. (2007). Organochlorine Pesticides in Placentas from Southern Spain and Some Related Factors. Placenta, Vol.28, No.7, (July 2007), pp. 631-638, ISSN 0143-4004.

López-Roldán, P.; López de Alda, M.J. \& Barceló, D. (2004). Simultaneous determination of selected endocrine disrupters (pesticides, phenols and phthalates) in water by in-field solid-phase extraction (SPE) using the prototype PROFEXS followed by on-line SPE (PROSPEKT) and analysis by liquid chromatography-atmospheric pressure chemical ionisation-mass spectrometry. Analytical and Bioanalytical Chemistry, Vol.378, No.3, (February 2004), pp. 599-609, ISSN 1618-2642

Mansilha, C.; Melo, A.; Rebelo, H.; Ferreira, I.M.; Pinho, O.; Domingues, V.; Pinho, C. \& Gameiro, P. (2010). Quantification of endocrine disruptors and pesticides in water by gas chromatography-tandem mass spectrometry. Method validation using weighted linear regression schemes. Journal of Chromatography A, Vol.1217, No.43, (October 2010), pp. 6681-6691, ISSN 0021-9673

Matisová, E. \& Dömötörová, M. (2003). Fast gas chromatography and its use in trace analysis. Journal of Chromatography A, Vol.1000, No.1-2, (June 2003), pp. 199-221, ISSN 0021-9673

Maštovská, K. \& Lehotay, S.J. (2003). Practical approaches to fast gas chromatography-mass spectrometry. Journal of Chromatography A, Vol.1000, No.1-2, (June 2003), pp. 153-180, ISSN 0021-9673 
Mendes, J.J. (2002). The endocrine disrupters: a major challenge. Food Chemistry and Toxicology, Vol.40, No.6, (June 2002), pp. 781-788, ISSN 0278-6915

Mnif, W.; Pillon, A.; Balaguer, P. \& Bartegi, A. (2007). Endocrine xenoestrogenics disrupters, molecular methods and detection methods. Therapie, Vol.62, No.5, (May 2007), pp. 369386, ISSN 0040-5957

Mnif, W.; Hassine, A.I.H; Bouaziz, A.; Bartegi, A.; Thomas, O. \& Roig, B. (2011). Effect of Endocrine Disruptor Pesticides: A Review. International Journal of Environmental Research and Public Health, Vol.8, No.6, (June 2011), pp. 2265-2303, ISSN 1660-4601

Mocák, J.; Balla, B.; Bobrowski, A. \& Blažíček, P. (2003). Proper Ways of Comparison of Two Laboratory Methods. Chemical Papers, Vol.57, No.3, (May 2003), pp. 143-146, ISSN 03666352

Nevado, J.J.B.; Cabanillas, C.G.; Llerena, M.J.V. \& Rodriguez Robledo, V. (2007). Sensitive SPE GC-MS-SIM screening of endocrine-disrupting herbicides and related degradation products in natural surface waters and robustness study. Microchemical Journal, Vol.87, No.1, (January 2003), pp. 62-71, ISSN 0026-265X

Peñalver, A.; Garcia, V.; Pocurull, E.; Borrull, F. \& Marcé, R.M. (2003). Stir bar sorptive extraction and large volume injection gas chromatography to determine a group of endocrine disrupters in water samples. Journal of Chromatography A, Vol.1007, No.1-2, (July 2003), pp. 1-9, ISSN 0021-9673

Petrovič, M.; Eljarrat, E.; López de Alda, M.J. \& Barceló, D. (2002). Recent advances in the mass spectrometric analysis related to endocrine disrupting compounds in aquatic environmental samples. Journal of Chromatography A, Vol.974, No.1-2, (October 2002), pp. 23-51, ISSN 0021-9673

Rhomberg, L. \& Seeley, M. (2005). Environmental Hormone Disruptors, In: Encyclopedia of Toxicology, P. Wexler (Ed.), pp. 205-208, Elsevier Press, ISBN 978-0-12-369400-3, San Diego, USA

Schulz, H.J. (2004). Pesticide Analysis Using the Agilent GC/MSD-a Compendium of EI/NCI data. Agilent Technologies, Publication Number 5989-0605EN, Germany

Serôdio, P. \& Nogueira, J.M.F. (2004). Multi-residue screening of endocrine disrupters chemicals in water samples by stir bar sorptive extraction-liquid desorption-capillary gas chromatography-mass spectrometry detection. Analytica Chimica Acta, Vol.517, No.1-2, (July 2004), pp. 21-32, ISSN 0003-2670

Sharma, S. (1996). Applied multivariate techniques, J. Wiley, ISBN 0-471-31064-6, New York

Trenholm, R.A.; Vanderford, B.J.; Holady, J.C.; Rexing, D.J. \& Snyder, S.A. (2006). Broad range analysis of endocrine disruptors and pharmaceuticals using gas chromatography and liquid chromatography tandem mass spectrometry. Chemosphere, Vol.65, No.11, (December 2006), pp. 1990-1998, ISSN 0045-6535

United States Environmental Protection Agency [US EPA] Document (2009). Final List of Initial Pesticide Active Ingredients and Pesticide Inert Ingredients to be Screened Under the Federal Food, Drug, and Cosmetic Act. Federal Register, Vol.74, No.71, (April 2009), pp. $17579-17585$ 
US EPA Document (2010). Endocrine Disruptor Screening Program; Second List of Chemicals for Tier 1 Screening. Federal Register, Vol.75, No.221, (November 2010), pp. 70248-70254

Van Dyk, J.S. \& Pletschke, B. (2011). Review on the use of enzymes for the detection of organochlorine, organophosphate and carbamate pesticides in the environment. Chemosphere, Vol.82, No.3, (January 2011), pp. 291-307, ISSN 0045-6535 